\title{
Multilayered low-strength geogrid-reinforced piled embankment
}

Kangyu Wang BEng, MSC

PhD candidate, Key Laboratory of Ministry of Education for Geomechanics and Embankment Engineering, Geotechnical Research Institute,

Hohai University, Nanjing, China

Yan Zhuang BEng, MSc, PhD

Professor, Key Laboratory of Ministry of Education for Geomechanics

and Embankment Engineering, Geotechnical Research Institute,

Hohai University, Nanjing, China (corresponding author:

zhuangyan4444@hotmail.com)
Hanlong Liu BEng, MSc, PhD

Professor, Key Laboratory of New Technology for Construction of Cities in Mountain Area of the Ministry of Education, Chongqing University, Chongqing, China

Henglin Xiao BEng, MSc, PhD

Professor, Key Laboratory of Ecological Remediation of Lakes and Rivers and Algal Utilization of Hubei Province, Hubei University of Technology, Wuhan, China

Multilayered low-stiffness geogrids have been used in constructing embankments, but without full understanding of their true behaviour - for example, the construction of apartments in Northern Ireland failed due to the excessive and continuing deformation of the load transfer platform. This paper presents a numerical simulation of multilayered geogrid-reinforced piled embankments. It shows that the inclusion of geogrids can effectively help transferring stress from subsoil to the pile cap, particularly for stiffer geogrids. Although the maximum settlement is approximately identical, an embankment with a three-layer geogrid provides more uniform stress distribution on the surface of subsoil and results in less differential settlement through the embankment. The maximum settlement and the total tension in the geogrid are found to be dependent only on the total stiffness provided and not on the number of geogrid layers. The parametric study shows that the combination of very soft subsoil and a geogrid with low stiffness results in relatively large settlement and may cause intolerable geogrid strain. The pile spacing is also found to be the most sensitive factor influencing the maximum settlement of the subsoil. Finally, an analytical method is assessed and shows reasonable agreement with the numerical results.

\section{Notation}

a width of the pile cap: $\mathrm{m}$

$a_{0} \quad$ initial yield surface size: $\mathrm{kPa}$

$C_{\mathrm{c}} \quad$ compression index of subsoil

$c^{\prime} \quad$ effective cohesion of the materials: $\mathrm{kPa}$

$e_{\mathrm{N}} \quad$ intercept of the normally consolidated line with void ratio axis in $\mathrm{e}-\ln p^{\prime}$ plane

$e_{0} \quad$ initial void ratio

$h_{\mathrm{e}} \quad$ height of the embankment: $\mathrm{m}$

$h_{\mathrm{s}} \quad$ thickness of the soft clay: $\mathrm{m}$

$J \quad$ tensile stiffness of the geogrid: $\mathrm{MN} / \mathrm{m}$

$k_{\mathrm{h}} / k_{\mathrm{v}} \quad$ coefficient of permeability in horizontal and vertical directions: $\mathrm{cm} / \mathrm{s}$

$k_{\mathrm{W}} \quad$ coefficients of permeability: $\mathrm{m} / \mathrm{d}$

$l \quad$ span of the tensile reinforcement: $\mathrm{m}$

M slope of the critical state line

$m_{\mathrm{v}} \quad$ coefficient of volume compressibility: $\mathrm{MPa}^{-1}$

$p_{0} \quad$ overburden pressure: $\mathrm{kPa}$

$S_{\mathrm{CR}} \quad$ stress concentration ratio

$S$ pile spacing: $\mathrm{m}$

$T$ tension in the reinforcement: $\mathrm{kN} / \mathrm{m}$

$u_{\mathrm{w}} \quad$ pore water pressure: $\mathrm{kPa}$

$\gamma \quad$ unit weight of the materials: $\mathrm{kN} / \mathrm{m}^{3}$

$\delta \quad$ maximum settlement of the subsoil: $\mathrm{mm}$

$\delta_{\mathrm{r}} \quad$ maximum settlement of the geogrid: $\mathrm{mm}$

$\varepsilon \quad$ reinforcement strain

$\kappa \quad$ slope of the swelling line

$\lambda \quad$ slope of the virgin consolidation line

\author{
$v \quad$ Poisson's ratio of the materials \\ $\sigma_{\mathrm{G}} \quad$ vertical stress at the base of the embankment including \\ the action of arching: $\mathrm{kPa}$ \\ $\sigma_{\mathrm{p}} \quad$ vertical stress exerted on the top of the pile caps: $\mathrm{kPa}$ \\ $\sigma_{\mathrm{r}} \quad$ vertical stress carried by the geogrid: $\mathrm{kPa}$ \\ $\sigma_{\mathrm{s}} \quad$ vertical stress at the surface of subsoil: $\mathrm{kPa}$ \\ $\phi_{\mathrm{i}} \quad$ interface friction angle between pile and its \\ surrounding soil: ${ }^{\circ}$ \\ $\phi^{\prime} \quad$ friction angle of the materials: ${ }^{\circ}$
}

\section{Introduction}

Recently, significantly increased traffic volumes have led to increased construction of highways and railways all over the world. The rapid development of highway construction requires builders to improve the level of design and construction, particularly in the eastern coast of China (Shen et al., 2013; Xu et al., 2013), Ariake Bay, Japan (Ma et al., 2011), the eastern coast of Singapore (Arulrajah and Bo, 2008; Bo et al., 2015) and the Bangkok Plain (Lorenzo and Bergado, 2004; Horpibulsuk et al., 2012), where thick layers of saturated soft clays exist. The construction of embankments overlying these soils often leads to large lateral pressures and movement, excessive settlements and slope and bearing failures, which usually result in long construction delays and costly remedial work (Jamsawang et al., 2016). In order to mitigate these potential problems and ensure the comfort and safety of moving vehicles, either single or multiple layers of geogrid have been successfully used in combination with piles to support embankments over soft clay 
foundation soils, in which the single-layer geogrid behaves as a tensioned membrane while a multilayer system acts as a stiffened platform (or like a plate) due to the interlock of geogrid with the surrounding soil (Han and Gabr, 2002; Zhang et al., 2007).

The geogrid manufactured from polymers plays an important role in improving the performance of piled embankments. Generally, single or multiple layers of geogrids are installed just above the pile head to increase the load transfer to the piles and to reduce the total and differential settlements (Ariyarathne and Liyanapathirana, 2015; Chen et al., 2016; Deb and Mohapatra, 2013; Huang and Han, 2009; Lu and Miao, 2015; Xing et al., 2014; Zhang et al., 2016; Zhuang and Wang, 2015; Zhuang et al., 2014). The tensile force of the geogrid is directly related to the service performance of the geogrid. Some guidelines for the calculation of the tensile force of geogrids in reinforced piled embankments have been developed in the past decades (BSI, 2010; GGS, 2011; Van Eekelen et al., 2011, 2015; Zhuang and Ellis, 2014, 2016; Zhuang et al., 2014). However, due to the complexity of the reinforced piled embankments, some of these methods are based on a wide range of conservative assumptions that give rise to conflicting results, particularly with respect to the degree of the load transfer and stress-strain developed in the geogrid (Abdullah and Edil 2007; Chen et al., 2010; Russell and Pierpoint, 1997; Stewart and Filz, 2005; Zhuang and Wang, 2015). There are no clear uniform code guidelines available for the design of geogrid in reinforced piled embankments.

Most research conducted so far has focused on the behaviour of a single-layered geogrid, and knowledge on the characteristics of multiple layers of geogrid in the embankment system is rather limited in the literature. Multiple layers of lower-strength geogrid are often referred to as a 'load transfer platform'. Guido et al. (1986) showed that for both geogrid and geotextiles, after an optimum number of layers or width of reinforcement, the bearing capacity did not increase. Guido et al. (1987) suggested that multiple layers of geogrid reinforcement increased the bearing capacity, which could be interpreted as an improved angle of friction (or otherwise enhanced strength) for the composite soil/ geogrid material. They showed that an arch in an embankment reinforced by multiple layers of geogrid was a triangle with $45^{\circ}$ angle in plane strain, and a similar pyramid in the threedimensional (3D) case. Bell et al. (1994) applied this finding to evaluate an embankment with two layers of geosynthetic reinforcement supported on vibroconcrete columns. Maddison et al. (1996) reported about the Second Severn Crossing, which was reinforced by two layers of Tensar SS2 geogrid with relatively low strength and has been considered as a successful case.

Since the load transfer in reinforced piled embankments is a complex phenomenon, numerical techniques are needed for accurately analysing their response. Full 3D analyses are performed to study the stress concentrations developed at the edge of the pile, the tensile forces and strains developed in the geosynthetic layer (Abdullah and Edil, 2007; Bhasi and
Rajagopal, 2014; Liu et al., 2007). However, full 3D numerical modelling can usually be very complicated, needs computers with a high processing power and also can be extremely time consuming depending on the complexity of the problem (Ariyarathne et al., 2012). Therefore, for practical limitation, many researchers have used the unit cell concept and 3D column model to study the performance of piled embankments (Bhasi and Rajagopal, 2014; Jenck et al., 2009; Yoo, 2010; Yoo and Kim 2009; Zhuang and Wang, 2015).

This paper presents a comprehensive investigation on the multiple layers of low-strength geogrid-reinforced piled embankment; the results are also compared with those for an embankment with a single-layer geogrid and one with no geogrid reinforcement. The appropriateness of the $3 \mathrm{D}$ column model is first validated by comparing with the results from the full 3D model and the measurement of the test embankment presented by Chen et al. (2010). A parametric study is also conducted on a number of influencing factors such as the compression index of subsoil, geogrid stiffness, embankment height and pile spacing. Finally, an analytical method is assessed by finite-element modelling (FEM) in terms of stress and maximum settlement of the geogrid.

\section{Finite-element modelling}

\section{General description}

A hypothetical reinforced piled embankment constructed on subsoil is considered, as shown in Figure 1(a). A $40 \mathrm{~m}$ wide embankment with $1 \mathrm{~V}: 1 \mathrm{H}$ side slopes is constructed on a uniform $10 \mathrm{~m}$ thick soft clay layer below which a rigid layer exists. The ground water table is located at the top of the clay layer. Concrete square piles, with a square pile cap of $1 \mathrm{~m}$ width and $0.5 \mathrm{~m}$ thickness, were assumed to be installed in a square grid pattern, and the width of the pile was $0.3 \mathrm{~m}$. The three-layer geogrid shown in Figure 1(b) is assumed to be placed at heights of $0 \cdot 1$, 0.4 and $0.7 \mathrm{~m}$ above the base of the embankment, while the single-layer geogrid was placed at a small height of $0 \cdot 1 \mathrm{~m}$, to prevent the risk of damage to the geogrid layer attributable to rubbing against the hard surface of the pile.

In this analysis, the compression index of the subsoil $\left(C_{\mathrm{c}}\right)$ and the stiffness of geogrid $(J)$ are varied, as summarised in Table 1. In Cam Clay, the compressibility is represented by the parameters $\lambda$ and $\kappa$. The parameter $\lambda$ is equal to $C_{\mathrm{c}}$ divided by $2 \cdot 3$, and it is assumed in this study that $\kappa$ is equal to $0 \cdot 1$ times $\lambda$. In the numerical parameter study, the following values of $C_{\mathrm{c}}$ are used: $0 \cdot 3,0 \cdot 7$ and $1 \cdot 5$. Based on manufactures' literature, the load which can be carried at 5\% strain of the geogrid in the short term covers a very wide range from about 20 up to about $500 \mathrm{kN} / \mathrm{m}$. The corresponding range of nominal stiffness is $0 \cdot 4-10 \mathrm{MN} / \mathrm{m}$. The stiffness of the geogrid chosen in this analysis $(J=0 \cdot 2,0 \cdot 5,1.5$ and $3 \mathrm{MN} / \mathrm{m})$ is thus relatively low and is not intended to represent a specific product. The embankment height $\left(h_{\mathrm{e}}\right)$ and the pile spacing $(s)$ are also varied, as shown in Figure 1(a). 

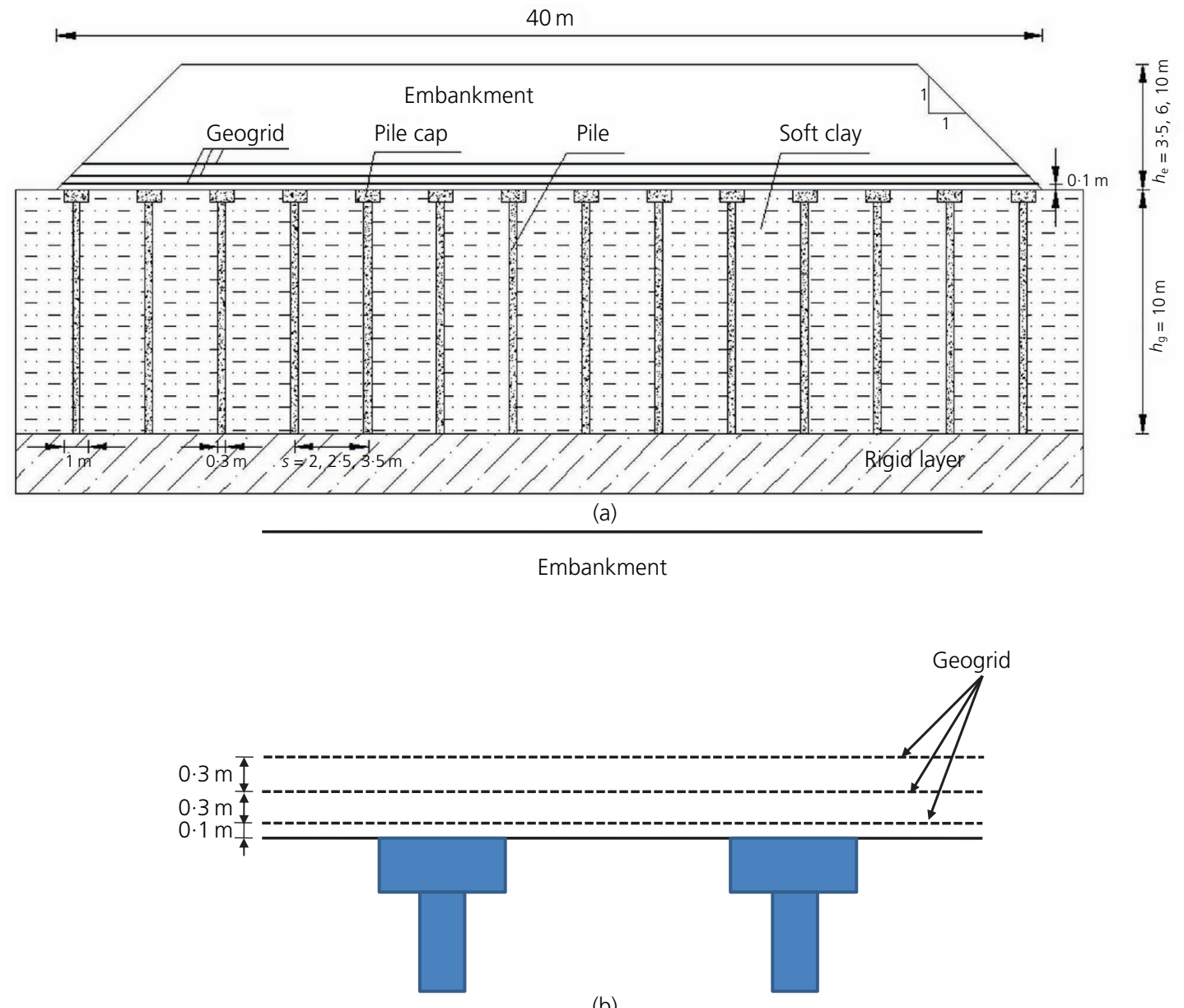

(b)

Figure 1. (a) Cross-section of the reinforced piled embankment; (b) layout of the three-layer geogrid in the reinforced piled embankment

Table 1. Summary of the material parameters used in the finite element analyses

\begin{tabular}{|c|c|c|c|c|c|c|c|c|c|}
\hline Material & $\gamma: \mathrm{kN} / \mathrm{m}^{3}$ & $c^{\prime}: \mathrm{kPa}$ & $\phi^{\prime}:{ }^{\circ}$ & E: MPa & $v$ & $\mathrm{C}_{\mathrm{c}}$ & $M$ & $e_{0}$ & $k_{\mathrm{w}} \times 10^{-4}: \mathrm{m} / \mathrm{d}$ \\
\hline Embankment & $18 \cdot 5$ & 3 & 35 & 20 & 0.3 & - & - & - & - \\
\hline Pile & $23 \cdot 5$ & - & - & 20000 & 0.2 & - & - & - & - \\
\hline Subsoil & $17 \cdot 0$ & - & 26 & - & 0.3 & $0.3,0.7$ or 1.5 & 1.027 & 1.79 & $4 \cdot 32$ \\
\hline Geogrid & $\begin{array}{l}\text { Tensile stiffne } \\
\text { geogrid mo }\end{array}$ & $\begin{array}{l}=0,0 \cdot 2, \\
=0\end{array}$ & $1.5 \mathrm{a}$ & $\mathrm{MN} / \mathrm{m} \mathrm{f}$ & ach la & of the three-laye & grid m & and 3 . & the single-layer \\
\hline
\end{tabular}

Figure 2 shows the finite-element (FE) mesh used in the analysis, together with the location of the geogrids for both three-layer and single-layer geogrid models. Due to symmetry, only one-quarter of the pile and its tributary area is modelled (Zhuang and Ellis, 2014, 2016; Zhuang et al., 2012). Thus, a 'unit cell' with square dimensions of half the pile spacing is used in the analyses, which are carried out using the FE package Abaqus (version 6.12). Corresponding to conditions of symmetry, the vertical boundaries of the cuboid are restrained against the horizontal movement normal to each face, and the base of the model is rigidly restrained in the vertical and horizontal directions. For the hydraulic boundary condition, the phreatic level is set at the top surface of the clay layer to generate a hydrostatic pore water pressure profile in the domain. A zero-pore pressure $\left(u_{\mathrm{w}}=0 \mathrm{kPa}\right)$ boundary condition is applied at the top and bottom boundaries to model free drainage, which means that the water is allowed to drain by way of the top and bottom surfaces of the soft clay. In the FE models, eight-node stress pore pressure-coupled brick elements (C3D8P) are used to represent the soft clay, while eightnode brick elements (C3D8) are used for the embankment fill and the pile. Due to the low bending rigidity, the geogrid can be strained only by tensile forces. When subjected to stresses that are perpendicular to the horizontal plane, the gegrid may take the shape of a membrane so that the tensile forces guarantee the static 

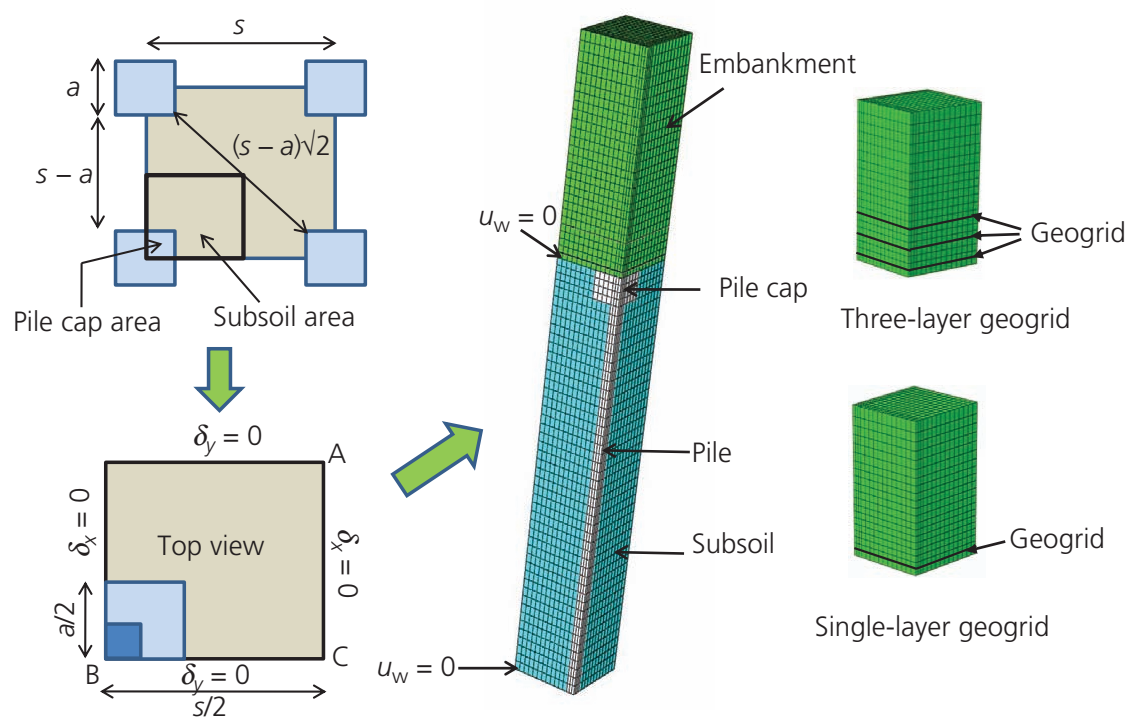

Three-layer geogrid

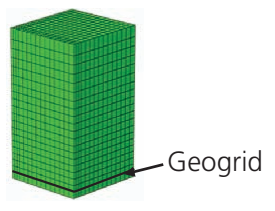

Single-layer geogrid

Figure 2. FE model used in the analysis

equilibrium of the sheet (Briancon and Villard, 2008). As a result, modelling the geogrid inclusion as a continuous membrane has proven to simulate the overall response of the geogrid-reinforced piled embankment reasonably ( $\mathrm{Gu}$ et al., 2016; Hussein and Meguid, 2016; Liu et al., 2007; Saad et al., 2006; Zhuang and Wang, 2015). The biaxial geogrid in this paper is represented using four-node, full integration, 3D membrane elements and is modelled as an orthotropic elastic material with the non-zero stiffness only in two orthogonal directions (Zhuang and Ellis, 2014).

\section{Constitutive models}

With regard to the constitutive modelling, the soft subsoil is modelled as modified Cam Clay (MCC) material. A linear elastic, perfectly plastic model with the Mohr-Coulomb failure criterion is used to model the embankment fill. The parameters used in the analysis are summarised in Table 1. The pile and geogrid are modelled as linear elastic material.

The contact behaviours at the pile-subsoil surface include load transfer mechanisms both in the normal and tangent directions. The normal force can only be transferred when the pile and the subsoil are contacted tightly and becomes zero otherwise (it becomes zero when the pile and the subsoil separates). This kind of normal contact behaviour can be modelled by a 'hard' contact option provided by Abaqus. The tangent behaviour can range from rough contact with no relative sliding between soil and pile to frictionless sliding conditions with no friction developing along the shaft of the pile. As a result, the Mohr-Coulomb failure criterion along with friction law is adopted to describe the frictional interface behaviour with a prescribed frictional coefficient $\mu=\tan \phi_{\mathrm{i}}$, in which $\phi_{\mathrm{i}}$ is the interface friction angle between the pile and the subsoil (Abdrabbo and Ali, 2015; Di Donna et al., 2015; Miao et al., 2016). The $\phi_{\mathrm{i}}$ can be determined as follows based on the equation proposed by Potyondy (1961) for the clay.

1. $\phi_{\mathrm{i}}=(0 \cdot 6-0 \cdot 8) \phi^{\prime}$

where $\phi^{\prime}$ is the friction angle of the soil. In this analysis, the ratio of the interface friction angle $\left(\phi_{\mathrm{i}}\right)$ and the friction angle of the soil $\left(\phi^{\prime}\right)$ is assumed as $0 \cdot 7$.

Knowledge on the interaction mechanism between the geogrid and embankment is of significance in the design and analysis of the geogrid-reinforced piled embankment. Stresses in the geogrid are transferred to the surrounding soil by the developed bonding between the embankment and the geogrid layer. This bond generally forms through friction, passive soil resistance or a combination of both. A hard contact option provided by Abaqus is again used to simulate the normal interaction between the geogrid and the subsoil, while the tangent behaviour is simulated using the Coulomb friction model with the interface modelled as rough (i.e. interface friction angle equals the friction angle of the embankment fill) (Liu et al., 2007; Perkins, 2000; Zhuang and Ellis, 2014).

In addition, the initial yield surface size $a_{0}$, a required input for the MCC model, is computed using the following.

2.

$$
a_{0}=\frac{1}{2} \exp \left[\left(1+e_{0}\right) \frac{e_{\mathrm{N}}-e_{0} \kappa \ln p_{0}}{\lambda-\kappa}\right]
$$

where $e_{0}$ is the initial void ratio; $p_{0}$ is the overburden pressure; $e_{\mathrm{N}}$ is the intercept of the normally consolidated line with void ratio axis 
in $e-\ln p^{\prime}$ plane; $\lambda$ is the slope of the virgin consolidation line; and $\kappa$ is the slope of the swelling line. The trend of increasing $a_{0}$ with depth is taken into consideration by dividing the clay layer into 20 vertical sections of equal thickness and assigning the computed $a_{0}$ value at mid-depth for each vertical section (Yoo, 2010).

\section{Simulation procedure}

The simulation procedure of this analysis was straightforward. After establishing the initial stress and pore pressure conditions together with the boundary condition, the embankment construction was simulated in five stages. The embankment loading is simulated by adding layers of elements simulating the fill in all models. Each embankment fill placement is assumed to be completed in $15 \mathrm{~d}$ and followed by a $10 \mathrm{~d}$ consolidation period. During this period, the subsoil is allowed to drain. A consolidation period of $200 \mathrm{~d}$, followed by the embankment construction, is carried out until the excess pore water pressure fell below a specified value (i.e. $0 \cdot 1 \mathrm{kPa}$ ).

\section{Model validation}

A test section G5 of the Shanghai-Jiangsu-Zhejiang-Anhui (SJZA) highway supported by tube piles reported by Chen et al. (2010) was used to validate the modelling approaches. The crosssection of the instrumented embankment and the soil profile is shown in Figure 3, with other information illustrated in detail in the paper by Chen et al. (2010).

In this study, both the full 3D modelling approach and the 3D column modelling approach were adopted for the analysis of the test embankment. Since the embankment was symmetrical along the centreline, only half of the embankment was modelled for the full 3D model (seen in Figure 4(b)). The foundation soil was taken to be $40 \mathrm{~m}$ deep overlying a rigid impermeable stratum. The horizontal length of the model was taken to be $72 \mathrm{~m}$ so that the boundary effect can be minimised. A $6.5 \mathrm{~m}$ wide section with three rows of piles beneath the embankment was selected for the analysis, so that a truly full $3 \mathrm{D}$ model can be obtained. As for the 3D column model (shown in Figure 4(a)), only one-quarter of the pile and its tributary area was modelled. The properties of the materials are summarised in Table 2, and the geogrid is modelled as an orthotropic linear elastic material herein.

The measured and FE results of the earth pressure, pore water pressure and the settlement are shown in Figure 5; the full 3D model and the 3D column model appeared to capture the general trend of the measured data well. As seen in Figure 5(a), the results of the full 3D model and 3D column model were found to agree well with the measurement and are both slightly overestimated, with an error of 21 and $13 \%$ for the pressure at the pile cap, while the error for the pressure at the soil surface is 19 and $8 \%$, respectively. The comparison of measured and FE computed pore water pressure variation at a depth of $20 \mathrm{~m}$ is shown in Figure 5(b). Both the full 3D model and 3D column model overestimate the value of the pore water pressure during the construction of the embankment, while underestimating the value during consolidation. This may be because the reduction of water permeability as a result of a decrease in void ratio during consolidation is not considered in the FE analyses. As shown in Figure 5(c), the results of the full 3D model and 3D column model show close agreement with the measurements, while the

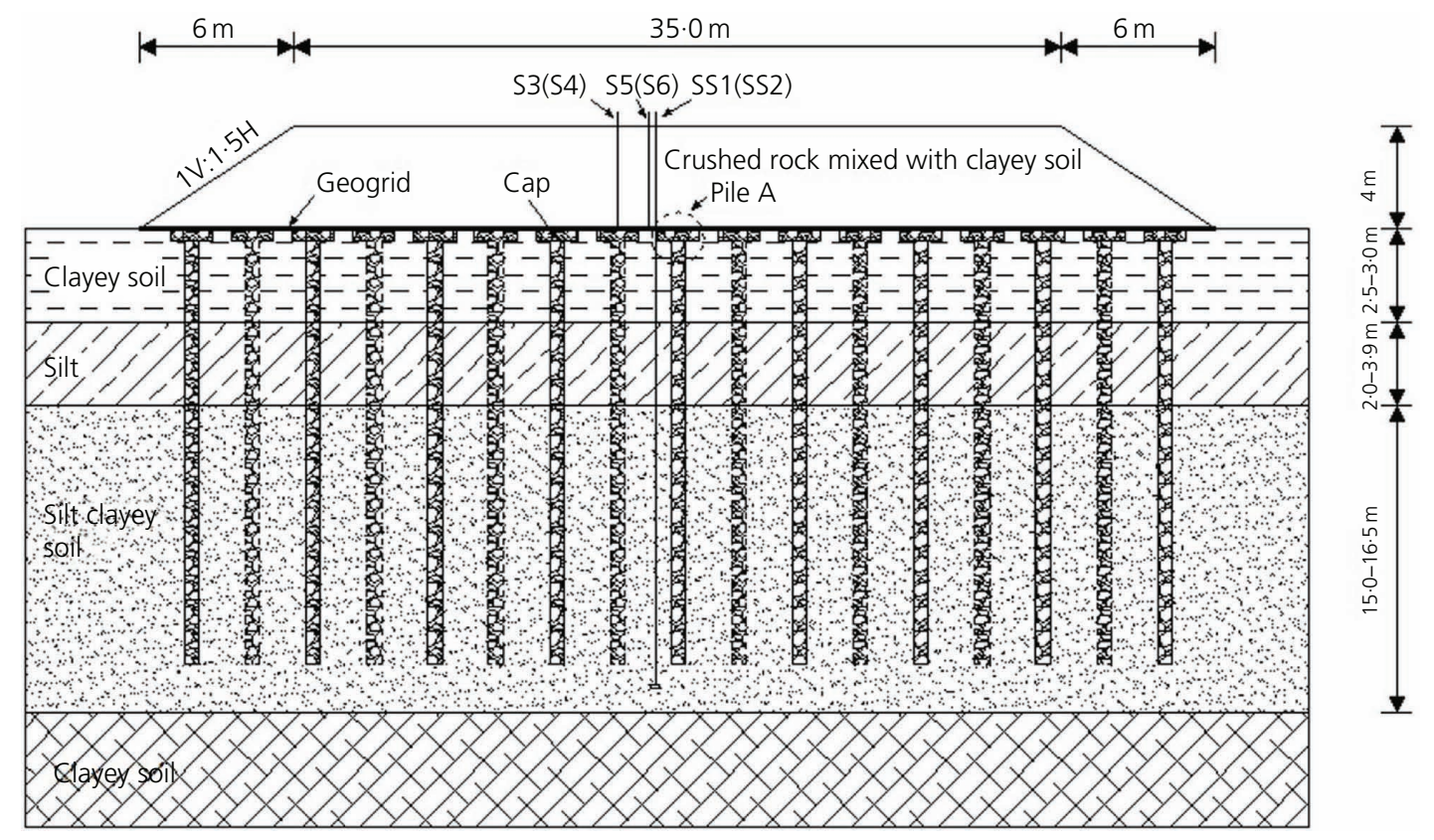

Figure 3. Cross-section of instrumented test embankment in SIZA highway (section G5) 


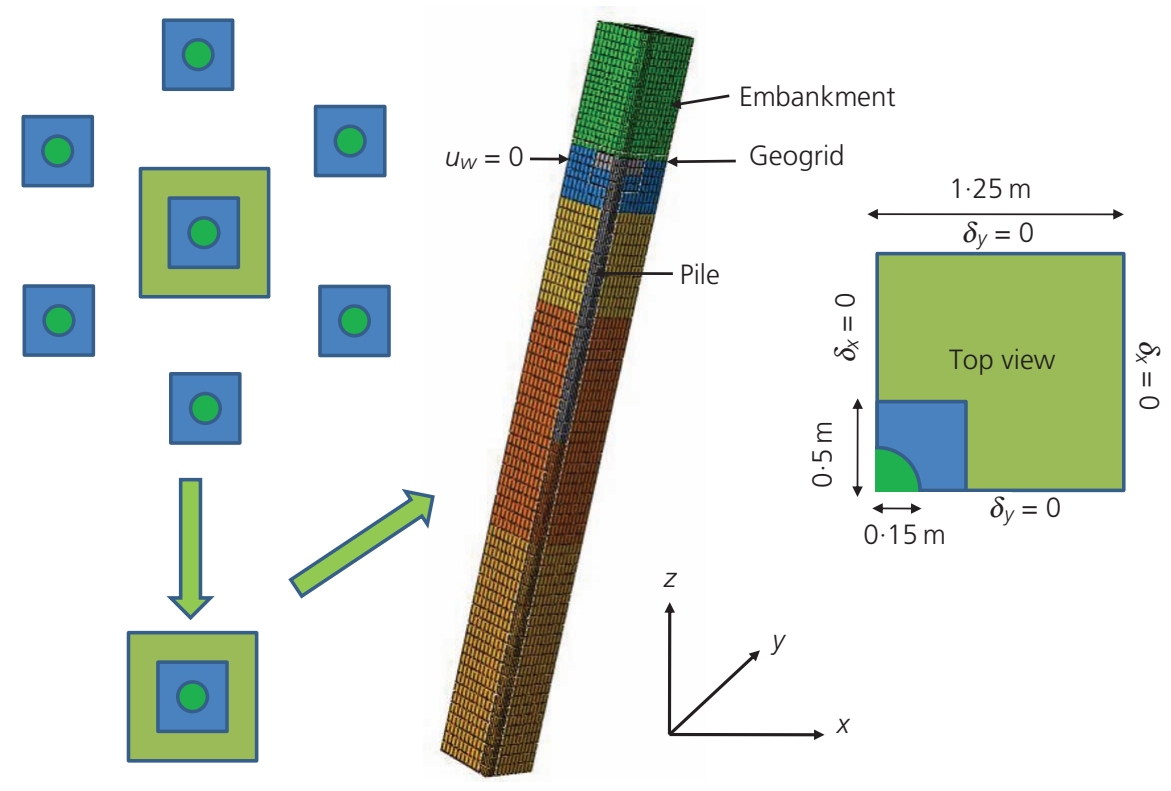

(a)

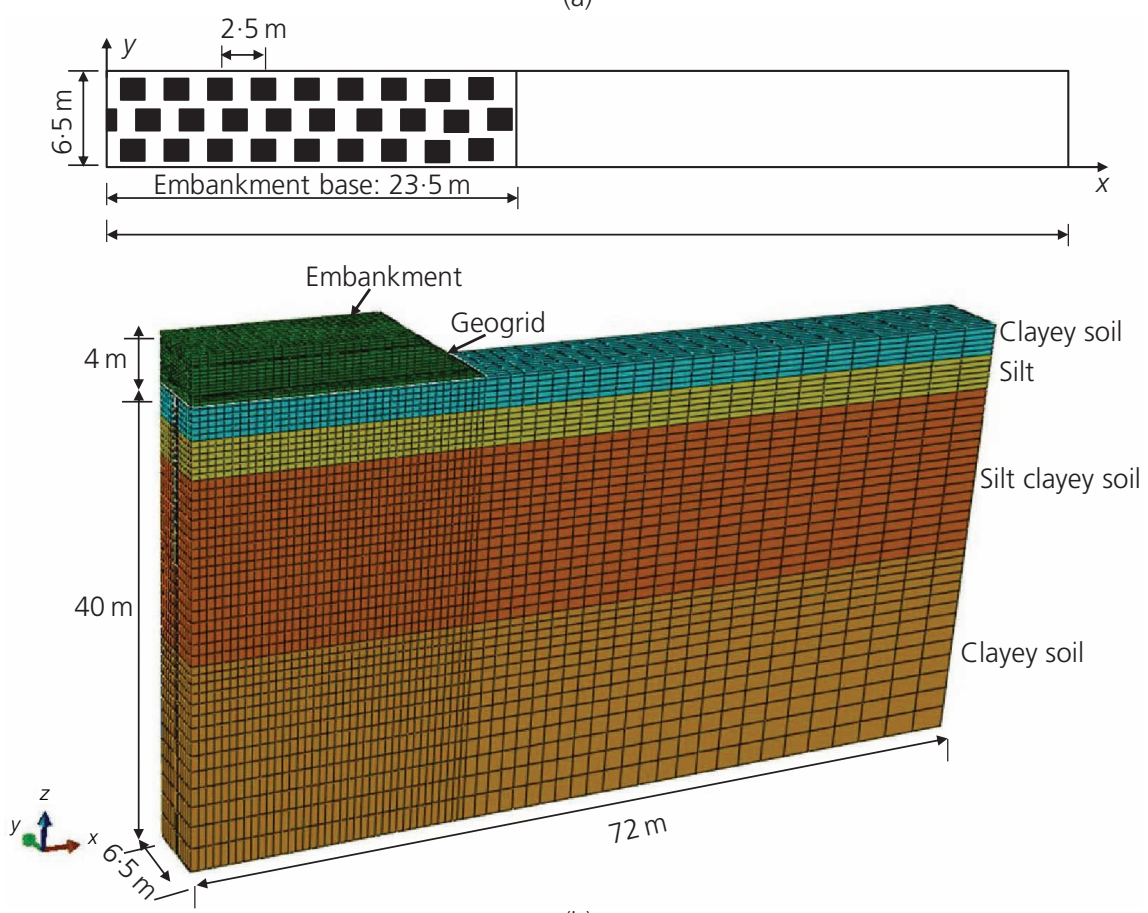

(b)

Figure 4. Three-dimensional models adopted for the validation: (a) 3D column model and (b) full 3D model

maximum settlements are both slightly overestimated, with the maximum error within $15 \%$. These results demonstrate that the proposed $3 \mathrm{D}$ column model is appropriate for modelling the reinforced piled embankment.

A close agreement was therefore observed among the results of the full 3D model, 3D column model and the measurement, demonstrating that the proposed $3 \mathrm{D}$ column model was appropriate to model the reinforced piled embankment.

\section{Comprehensive analysis of three layers of low-strength geogrid}

The results of the three layers of low-strength geogrid-reinforced piled embankments are presented in some detail. The analyses are based on the standard values $\left(s=2.5 \mathrm{~m}, h_{\mathrm{e}}=6 \mathrm{~m}, C_{\mathrm{c}}=0.7\right)$ and variation with the geogrid stiffness, also including the cases with a single geogrid layer and no geogrid reinforcement. The comparison between three-layer and single-layer geogrids is conducted based on the same total stiffness. 
Table 2. Summary of the parameters used for model validation

\begin{tabular}{|c|c|c|c|c|c|c|c|}
\hline Layer & Thickness: m & $\gamma: \mathrm{kN} / \mathrm{m}^{3}$ & $e_{0}$ & $k_{\mathrm{h}} / k_{\mathrm{v}}: 10^{-6} \mathrm{~cm} / \mathrm{s}$ & $m_{\mathrm{v}}: \mathrm{MPa}^{-1}$ & $c^{\prime}: \mathrm{kPa}$ & $\phi^{\prime}: \circ$ \\
\hline Clayey soil & $2 \cdot 5-3 \cdot 0$ & $19 \cdot 1$ & 0.801 & $7 \cdot 50 / 7 \cdot 90$ & 0.189 & 0 & 24 \\
\hline Silt & $2 \cdot 0-3 \cdot 9$ & $17 \cdot 3$ & $1 \cdot 312$ & $0.91 / 0.25$ & 0.681 & 0 & 20 \\
\hline Silt clayey soil & $15 \cdot 0-16 \cdot 5$ & $17 \cdot 1$ & $1 \cdot 290$ & $0 \cdot 10 / 0 \cdot 11$ & 0.483 & 0 & 22 \\
\hline Clayey soil & $18 \cdot 5-23 \cdot 2$ & 18.9 & 0.788 & $7 \cdot 22 / 7 \cdot 61$ & 0.145 & 0 & 25 \\
\hline
\end{tabular}

$\gamma$, unit weight; $e_{0}$, void ratio; $k_{h} / k_{v}$, coefficient of permeability in horizontal and vertical directions; $m_{v}$, coefficient of volume compressibility; $c^{\prime}$, effective cohesion; $\phi$, effective friction angle

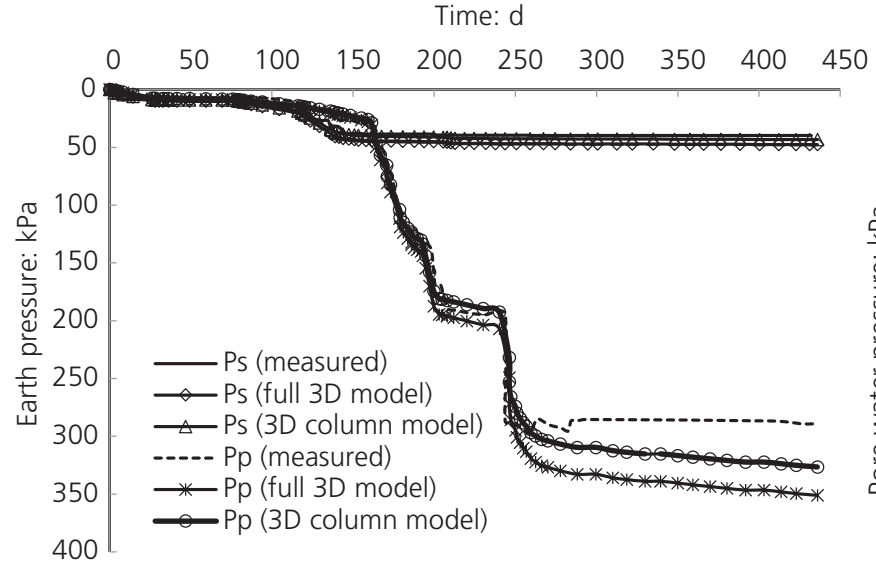

(a)

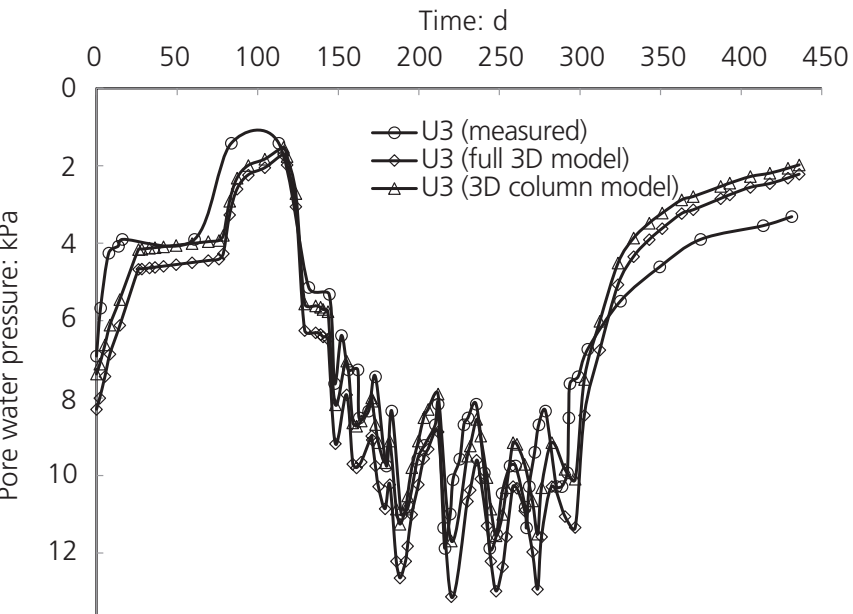

(b)

Time: $\mathrm{d}$

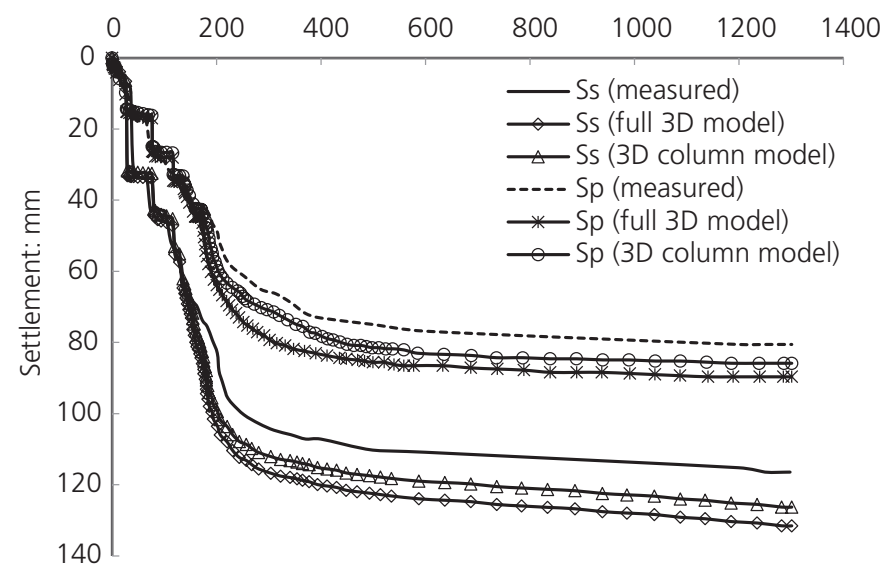

(c)

Figure 5. Measurements against FE computed results: (a) earth pressure, (b) pore water pressure and (c) settlement

\section{Subsoil stress $\left(\sigma_{\mathrm{s}}\right)$ and geogrid stress $\left(\sigma_{\mathrm{r}}\right)$}

Zhuang et al. (2014) proposed a simplified model to analyse the reinforced piled embankment by considering the arching effect, tensile force of reinforcement and subgrade reaction. For equilibrium, the vertical stress immediately below the reinforcement between the pile caps can be given by

3. $\sigma_{\mathrm{s}}=\sigma_{\mathrm{G}}-\sigma_{\mathrm{r}}$ where $\sigma_{\mathrm{s}}$ is the vertical stress carried by the subsoil; $\sigma_{\mathrm{r}}$ is the vertical stress carried by the geogrid. $\sigma_{\mathrm{G}}$ can be based on the 'ground reaction curve' (GRC) concept proposed by Iglesia et al. (1999) for arching over underground structures. Based on the 3D FEM of the embankment arching for uniform subsoil support, Zhuang et al. (2012) reported that the minimum stress $\left(\sigma_{\mathrm{G}, \mathrm{min}}\right)$ is reached when $\delta$ was less than $4 \%$ of the clear spacing between pile caps $(s-a)$, and prior to the minimum, $\sigma_{\mathrm{G}}$ initially reduces very rapidly with $\delta$. It is assumed that $\sigma_{\mathrm{G}}=\sigma_{\mathrm{G}, \min }$, where the value can potentially be derived 
from a wide range of methods (e.g. as compared by Ellis and Aslam (2009)), assuming that the embankment is sufficiently high for arching to occur (e.g. Zhuang et al., 2012). $\sigma_{\mathrm{G}}$ will be determined based on the FEM for the embankment supported by a uniform subsoil stress, as reported by Zhuang et al. (2012).

Figure 6 shows the results of vertical stress carried by the subsoil $\left(\sigma_{\mathrm{s}}\right)$ and the geogrid $\left(\sigma_{\mathrm{r}}\right)$ along the horizontal line BC (Figure 2) at the edge of the FE mesh and the diagonal BA. Note that on BC and BA, there are no data for distances less than 0.50 and $0.71 \mathrm{~m}$, respectively, since this would be above the pile cap $(a / 2=$ $0.50 \mathrm{~m}$ ) rather than in the subsoil. Likewise, points $\mathrm{C}$ and $\mathrm{A}$ are reached at 1.25 and $1.77 \mathrm{~m}(s / 2=1.25 \mathrm{~m})$.

The ' $\sigma_{\mathrm{G}}$ ' line (dotted line) in Figures $6(\mathrm{a})$ and $6(\mathrm{~b})$ shows the uniform value of embankment arching stress of $18 \mathrm{kPa}$, obtained in the same way as Zhuang et al. (2012). In order to obtain the $\sigma_{\mathrm{G}}$, an FE model presented by Zhuang et al. (2012) is developed, which is again the $3 \mathrm{D}$ column model without the pile and subsoil. The base of the mesh (embankment) consists of one-quarter of a pile cap and the interface with the subsoil below (seen in Figure 2). The pile cap was modelled as a rigid restraint to the overlying embankment in the vertical and horizontal directions. Over the area of the subsoil, there was no kinematic restraint to the underside of the embankment, but a uniform vertical stress $\left(\sigma_{\mathrm{s}}\right)$ was applied acting upwards to support the fill and represent the presence of the subsoil. This 'subsoil stress' was used to control the analysis, reducing from an initial value equal to the nominal vertical stress from the embankment $\left(\sigma_{\mathrm{s}}=\gamma h_{\mathrm{e}}\right)$. As expected, the non-uniform settlement of the embankment was observed at the base of the mesh (embankment) and was largest at the corner - point $\mathrm{A}$ (Figure 2). Based on the concept of GRC proposed by Iglesia et al. (1999), the variation of 'subsoil stress' $\left(\sigma_{\mathrm{s}}\right)$ with the settlement $\left(\delta_{\mathrm{s}}\right)$ at the point of maximum arching is plotted, and a constant value of $\sigma_{\mathrm{s}}$ can be reached at larger displacement. The ultimate subsoil stress is therefore obtained and is designated as $\sigma_{\mathrm{G}}$.

$\sigma_{\mathrm{s}}$ tends to a relatively small value near the pile cap, which is due to the stress transferring to the pile cap, and increases to a uniform value towards $\mathrm{C}$ or $\mathrm{A}$. As expected, the inclusion of the geogrid can effectively transfer the vertical stress from the subsoil to the pile cap, with an approximately $30 \%$ reduction of the vertical stress acting on the subsoil, particularly for stiffer geogrid. The three-layer geogrid is found to reduce more vertical stress

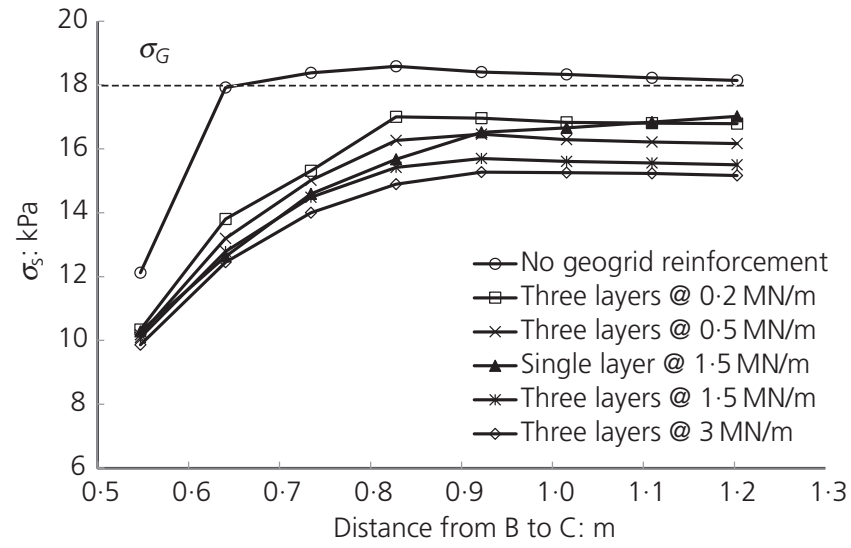

(a)

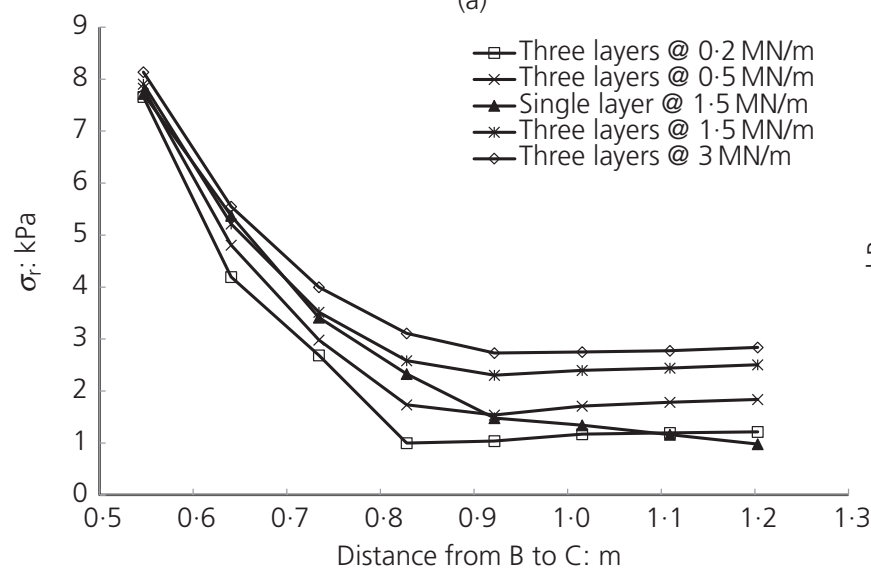

(c)

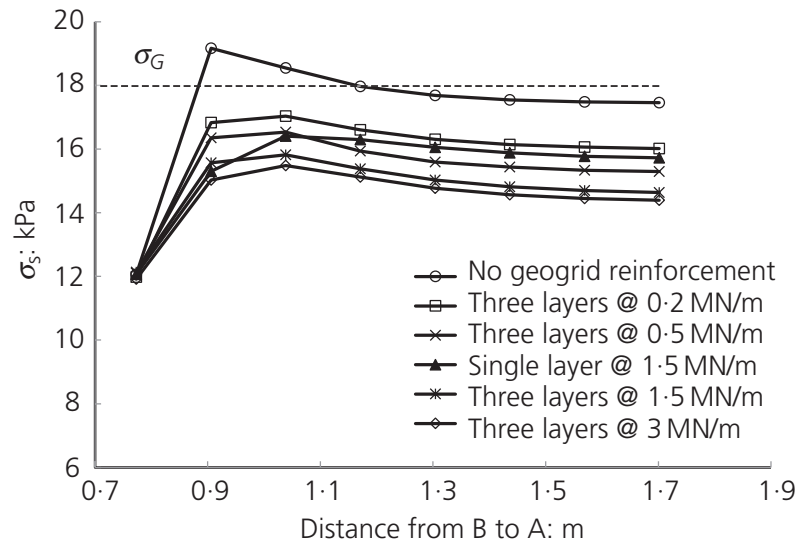

(b)

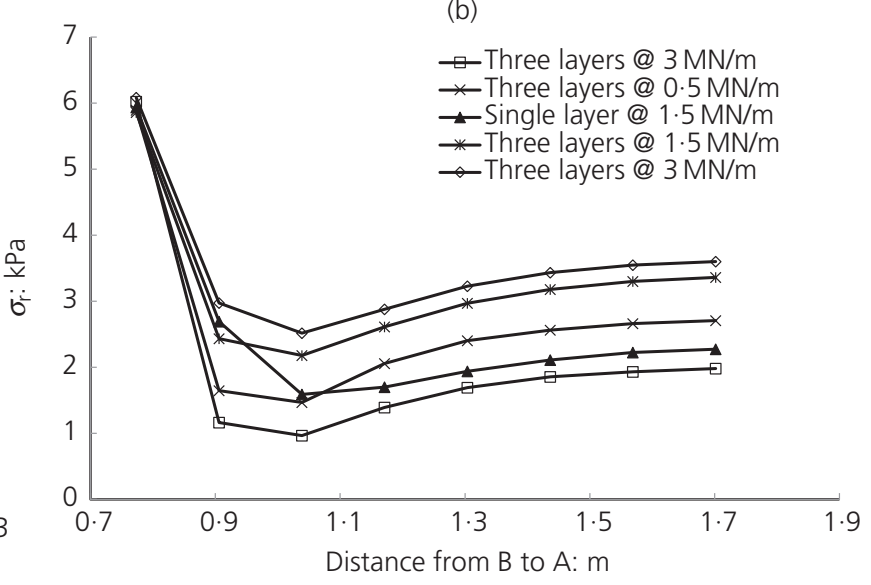

(d)

Figure 6. Distribution of subsoil stress $\left(\sigma_{\mathrm{s}}\right)$ and geogrid stress $\left(\sigma_{\mathrm{r}}\right)$ and variation of geogrid stiffness $\left(\mathrm{s}=2.5 \mathrm{~m}, h_{\mathrm{e}}=6 \mathrm{~m}\right)$ : (a) $\sigma_{\mathrm{s}}$ from B to $\mathrm{C}$ (edge); (b) $\sigma_{\mathrm{s}}$ from B to A (diagonal); (c) $\sigma_{\mathrm{r}}$ from B to C (edge); and (d) $\sigma_{\mathrm{r}}$ from B to A (diagonal) 
acting on the subsoil and results in a more uniform distribution of the vertical stress compared with the single-layer geogrid, particularly along the edge line $\mathrm{BC}$, as also illustrated by Briancon and Simon (2012).

The data in Figures 6(c) and 6(d) indicate that the vertical stress carried by the geogrid is localised near the pile cap, tending towards a relatively high value of stress over the pile cap. Moving from the edge of the pile cap towards $\mathrm{C}$ or $\mathrm{A}, \sigma_{\mathrm{r}}$ reduces and approaches a limiting value. As anticipated, the vertical stress carried by the geogrid increases with the stiffness. The three-layer geogrid carries more and uniformly distributed vertical stresses near point $\mathrm{C}$ or $\mathrm{A}$, while there is less vertical stress near the pile cap compared with the single-layer geogrid.

\section{Settlement $(\delta)$ in the geogrid}

Figure 7 shows the settlement of the geogird along $\mathrm{BC}$ and $\mathrm{BA}$ (in Figure 2). The data now start from $\mathrm{B}$ (distance $=0$ ), and the vertcial dotted lines indicate the edge of the pile cap $($ distance $=$ 0.50 or $0.71 \mathrm{~m})$.

Figures 7(a) and 7(b) show the settlement of the geogrid (or at the surface of the subsoil for no geogrid reinforcement). As expected, the case of no geogrid reinforcement gives the largest settlement, which is approximately $25 \%$ larger than the reinforced case (e.g. $J=0.5 \mathrm{MN} / \mathrm{m}$ ), and the settlement reduces as the geogrid stiffness increases. This may be attributed to the fact that the membrane effect increases with the increase of geogrid stiffness and, therefore, decreases the differential settlement between the pile caps and the subsoil. The settlement increases very rapidly at the edge of the pile cap, but is quite flat at 'midspan' (e.g. compared to a parabola), particularly at point A. The settlement at A is only slightly larger than that at C. These observations are consistent with analytically deformed shapes for geosynthetic reinforcement as proposed by Jones et al. (2010) and Halvordson et al. (2010). The settlements of the three-layer and single-layer geogrids are similar, only with marginal difference within $5 \%$, demonstrating that the settlement of the geogrid is dependent only on the total stiffness provided and not on the number of reinforcement layers.

\section{Tension in the geogrid}

Figure 8 shows the 3D figures of tension in geogrid along the $x$ direction for single-layer and three-layer geogrids. The horizontal axes $(x, y)$ show the normalised distance between the pile caps' centres, and hence, the corners of the plot are pile cap centres. In fact, only one-quarter of this area was modelled, but this has been used to produce a 'full' plot. The corners of the pile caps are at $(0 \cdot 2,0 \cdot 2),(0 \cdot 2,0 \cdot 8)$ and so on, on the horizontal axes. The general shape of the plots for the bottommost layer of the threelayer geogrid and the single-layer geogrid show excellent correspondence with Halvordson et al. (2010). Most notably, the maximum tensions of each geogrid layer all occurred at the corner of the pile cap and give values of $4 \cdot 3,6.7$ and $11 \cdot 2 \mathrm{kN} / \mathrm{m}$ for the upper-, middle- and bottom-layer geogrids, respectively. The upper two layers of the geogrid were found to carry relatively little tension compared to the bottom layer, as also illustrated in the paper by Bhasi and Rajagopal (2014), implying less effective performance. Also observed is that the sum of the maximum tension for the three-layer geogrid is approximately identical to that of the single-layer geogrid.

\section{Parametric study}

In order to investigate comprehensively the behaviour of multiple layers of lower-strength geogrid-reinforced piled embankments, the influence of the factors related to the compression index of subsoil $\left(C_{\mathrm{c}}\right)$, stiffness of geogrid $(J)$, embankment height $\left(h_{\mathrm{e}}\right)$ and pile spacing $(s)$ are studied, as summarised in Table 3.

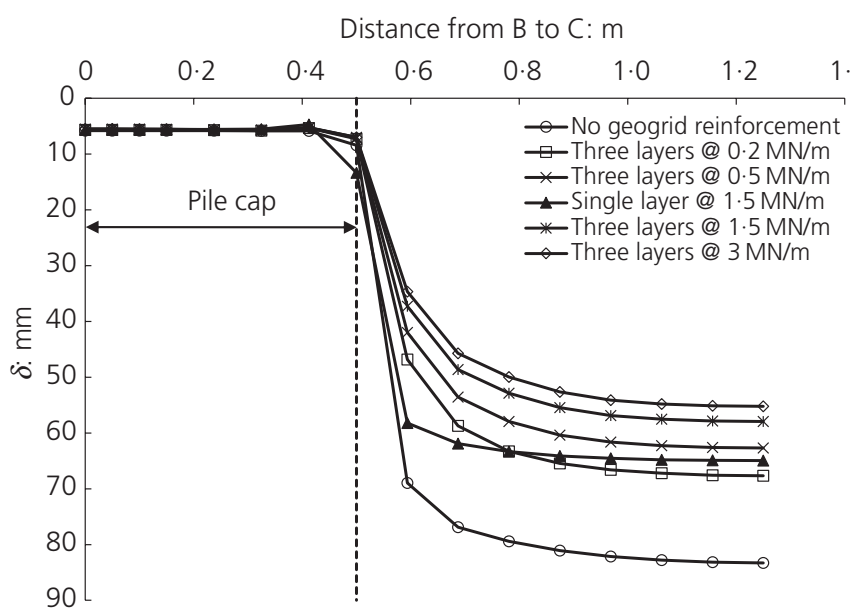

(a)

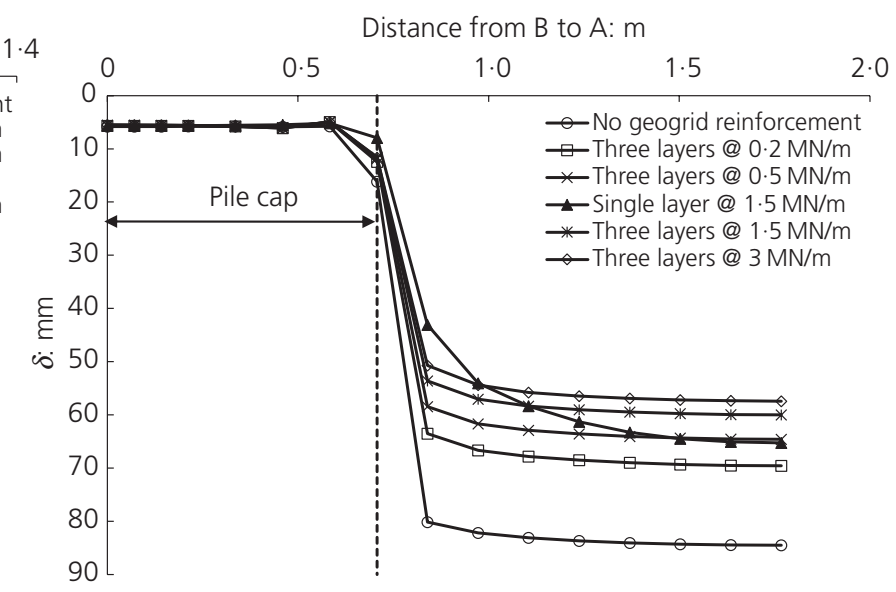

(b)

Figure 7. Distribution of settlement $\left(\delta\right.$ ) and variation of geogrid stiffness $\left(s=2.5 \mathrm{~m}, h_{\mathrm{e}}=6 \mathrm{~m}\right.$ ): (a) $\delta$ from B to C (edge) and (b) $\delta$ from B to A (diagonal) 


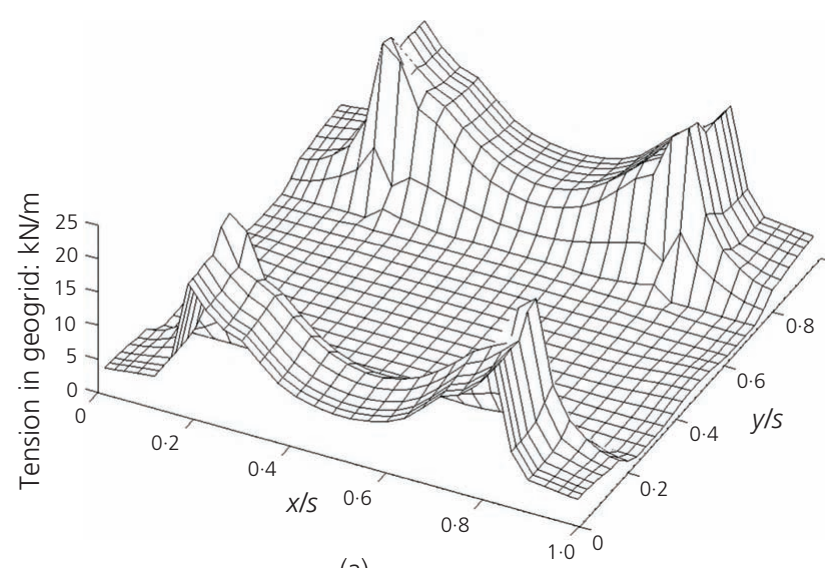

(a)

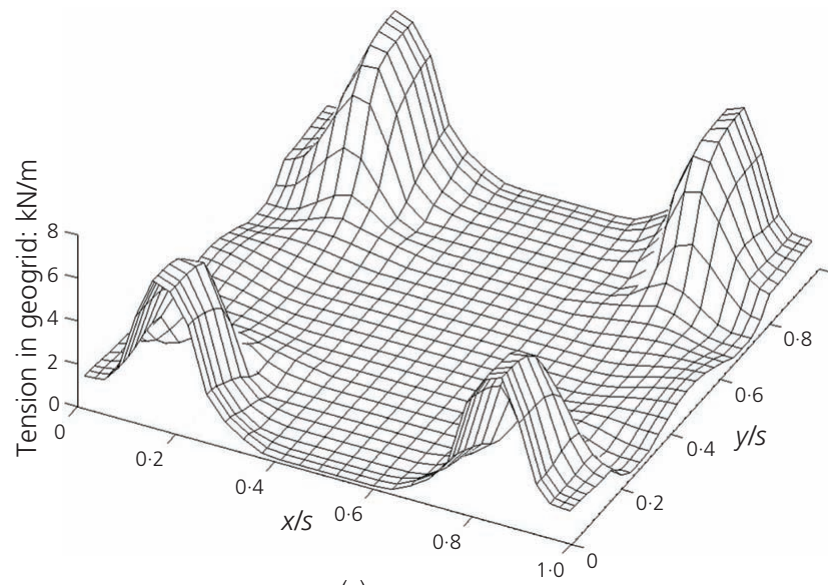

(c)
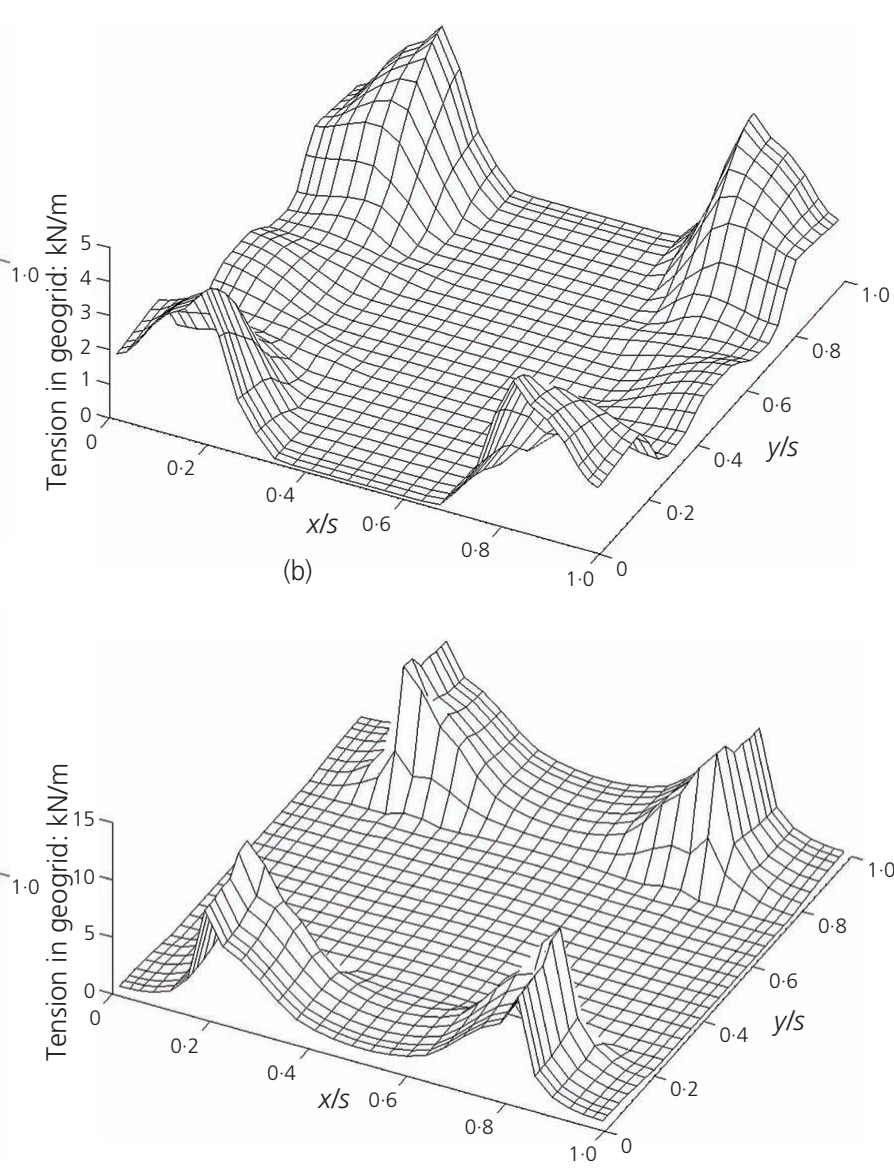

(d)

Figure 8. Tension in the geogrid for single-layer and three-layer geogrids ( $s=2.5 \mathrm{~m}, h_{\mathrm{e}}=6 \mathrm{~m}$, total stiffness $\left.=1.5 \mathrm{MN} / \mathrm{m}\right)$ : (a) single-layer geogrid; (b) upper-layer geogrid; (c) middle-layer geogrid; and (d) bottom-layer geogrid

\section{Effect of compression index of subsoil}

The effect of the compression index of subsoil on the maximum settlement of subsoil, subsoil stress and stress concentration ratio $\left(S_{\mathrm{CR}}\right)$ is shown in Figure 9. The maximum settlement of subsoil $(\delta)$ in Figure 9(a), which is normalised by dividing the clear pile

Table 3. Summary of analyses presented in parametric study

\begin{tabular}{lcccc} 
Parameter & $\boldsymbol{C}_{\mathbf{c}}$ & J: $\mathbf{M N} / \mathbf{m}$ & $\boldsymbol{h}_{\mathbf{e}}: \mathbf{m}$ & $\boldsymbol{s}: \mathbf{m}$ \\
\hline Compression index of subsoil, $C_{\mathrm{c}}$ & 0.3 & 0.5 & 6.0 & 2.5 \\
& 0.7 & 0.5 & 6.0 & 2.5 \\
& 1.5 & 0.5 & 6.0 & 2.5 \\
Tensile stiffness of geogrid, J & 0.7 & 0 & 6.0 & 2.5 \\
& 0.7 & 0.2 & 6.0 & 2.5 \\
& 0.7 & 1.5 & 6.0 & 2.5 \\
Embankment height, $h_{\mathrm{e}}$ & 0.7 & 3.0 & 6.0 & 2.5 \\
Pile spacing, s & 0.7 & 0.5 & 3.5 & 2.5 \\
& 0.7 & 0.5 & 10.0 & 2.5 \\
& 0.7 & 0.5 & 6.0 & 2.0 \\
& 0.7 & 0.5 & 6.0 & 3.5
\end{tabular}

$J$ is the stiffness of each layer geogrid for the three-layer geogrid model, and the stiffness of geogrid for the single-layer geogrid model corresponds to $3 \mathrm{~J}$; $J=0$ represents no geogrid reinforcement spacing $(s-a)$, is found to increase approximately linearly with increasing compression index of subsoil and increases by 40 and $52 \%$ as the compression index of subsoil increases from 0.3 to 0.7 and from 0.7 to 1.5 , respectively. The embankments constructed over very soft subsoil would result in a relatively large settlement and may cause excessive and continuing deformation. As shown in Figure 9(b), the stress carried by the subsoil decreases with an increase of the compression index of subsoil, but with a relatively low reduction ratio, implying an increased trend of the soil arching due to the modulus difference between the pile cap and the subsoil, which transfers the majority of the vertical stress from the subsoil to the pile cap. However, this development of soil arching is marginal when the subsoil is soft enough. The degree of stress concentration from the soil to the piles is typically evaluated by using the $S_{\mathrm{CR}}$, which is defined as the ratio of the stress on the pile caps to that on the subsoil and is given by

4. $S_{\mathrm{CR}}=\frac{\sigma_{\mathrm{p}}}{\sigma_{\mathrm{s}}}$ 


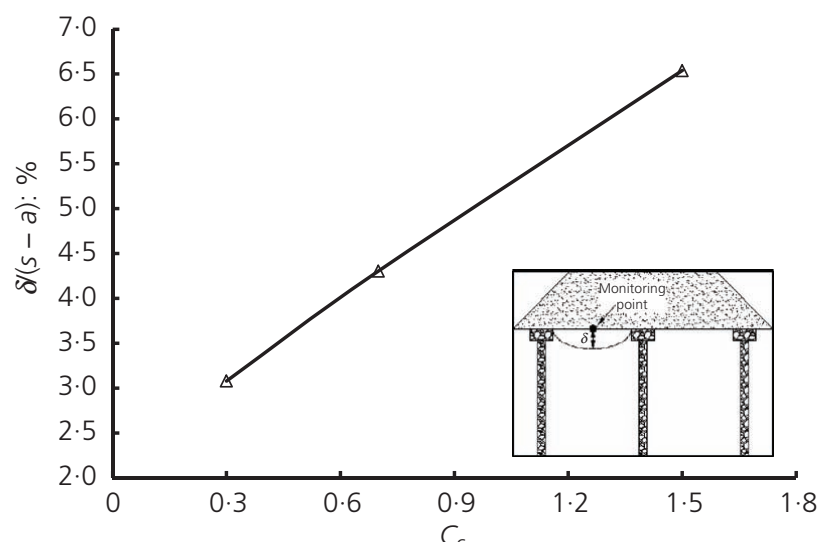

(a)

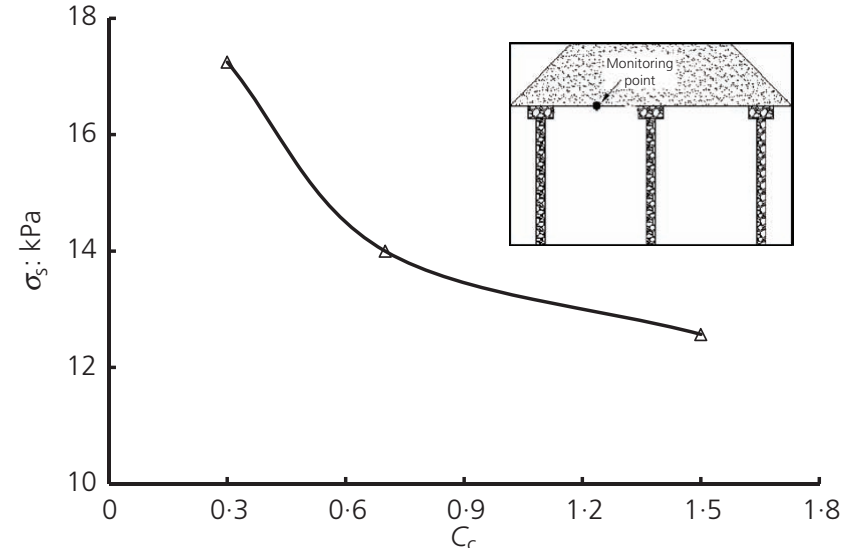

(b)

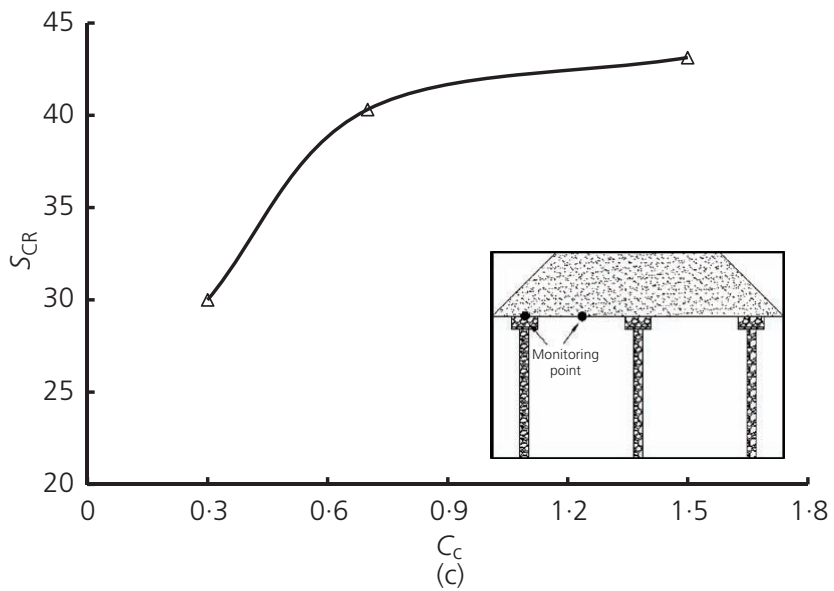

Figure 9. Effect of compression index of subsoil on the maximum settlement of subsoil, subsoil stress and $S_{C R}$ : (a) maximum settlement of the subsoil; (b) subsoil stress $\left(\sigma_{\mathrm{r}}\right)$; and (c) $S_{\mathrm{CR}}$

where $\sigma_{\mathrm{p}}$ is the vertical stress acting on the pile caps and $\sigma_{\mathrm{s}}$ is the vertical stress acting on the subsoil. The higher the concentration ratio, the more stress is transferred onto the piles. Consistent with the findings from the subsoil stress, the $S_{\mathrm{CR}}$ in Figure $9(\mathrm{c})$ increases as the compression index of subsoil increases, demonstrating that more vertical stress is transferred from the subsoil to the pile caps.

\section{Effect of geogrid stiffness}

The stiffness of the geogrid plays an important role in enhancing the load transfer from the subsoil to the pile cap and reducing the settlement of the embankment, as shown in Figure 10. Note that the case of $J=0 \mathrm{MN} / \mathrm{m}$ in fact represents no geogrid reinforcement. As anticipated, the settlement of the subsoil in Figure 10(a) is significantly reduced by an increase in the stiffness of the geogrid and then reaches a limiting value (the dotted line) when the stiffness of each layer of geogrid exceeds $1.5 \mathrm{MN} / \mathrm{m}$ in this analysis. The maximum settlement of the subsoil decreases by $29 \%$ as the geogrid stiffness increases from 0 to $1.5 \mathrm{MN} / \mathrm{m}$, while any further increase in the geogrid stiffness approximately does not result in any further reduction in the settlement. With the increase of the geogrid stiffness, the differential settlement between the pile cap and the subsoil decreases, which leads to a reduction of the soil arching effect. However, the membrane effect of the geogrid increases as the geogrid stiffness increases and results in a decrease of the stress carried by the subsoil and an increase of the $S_{\mathrm{CR}}$, as shown in Figures 10 (b) and 10(c). As a result, the majority of the vertical stress is transferred from the subsoil to the pile cap and therefore increases the soil arching effect with the increase in the geogrid stiffness, particulary when the geogrid stiffness is relatively low. Similarly, only limited influence is observed when the geogrid stiffness is sufficiently large (i.e. larger than $1.5 \mathrm{MN} / \mathrm{m}$ ).

\section{Effect of embankment height}

Figure 11(a) shows that the maximum settlement of the subsoil increases with an increase in the embankment height, and increases by approximately $62 \%$ when the embankment height increases from 6 to $10 \mathrm{~m}$. As for a higher embankment, the vertical stress acting on the subsoil increases due to the increase in the overborne weight from the embankment (Figure 11(b)), and the $S_{\mathrm{CR}}$ increases since the shear resistance accumulates for 


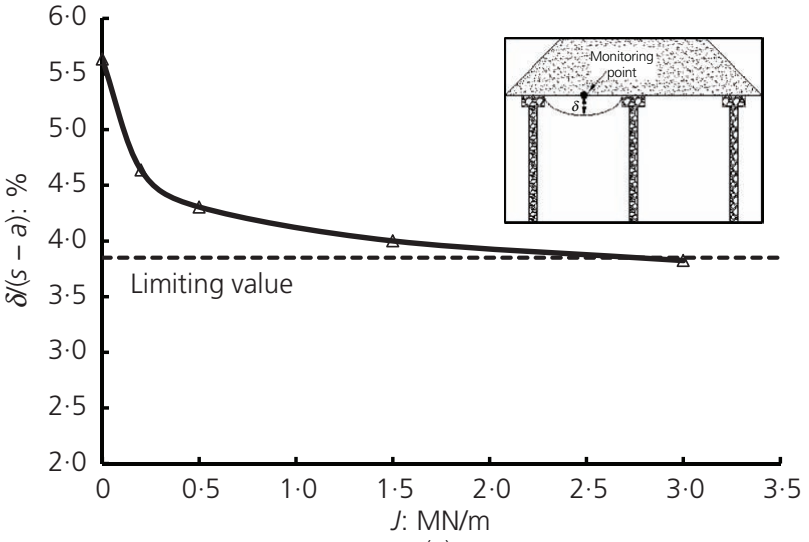

(a)

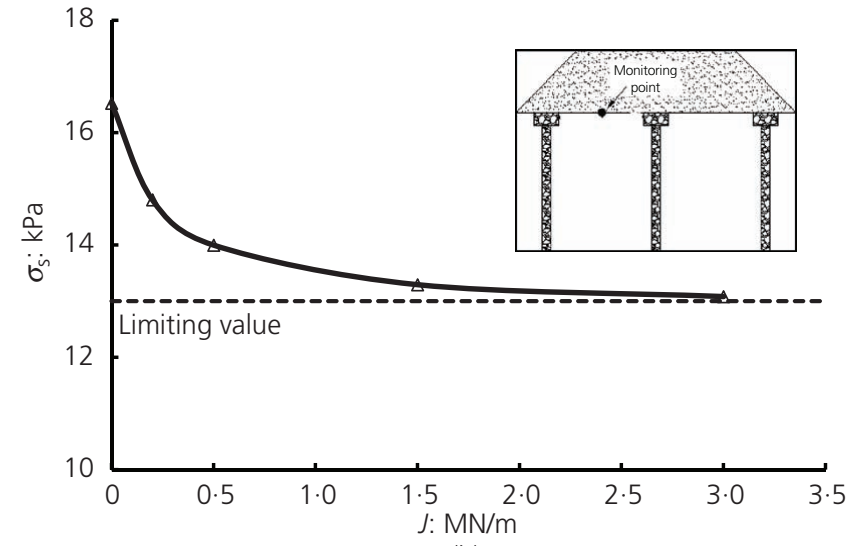

(b)

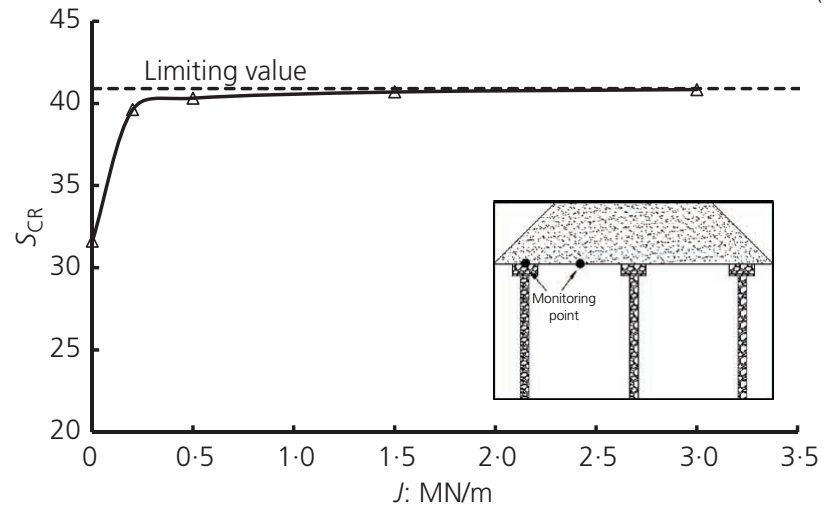

(c)

Figure 10. Effect of the geogrid stiffness on the maximum settlement of subsoil, subsoil stress and $S_{C R}$ : (a) maximum settlement of the subsoil; (b) subsoil stress $\left(\sigma_{\mathrm{r}}\right)$; and (c) $S_{\mathrm{CR}}$

enhancing the development of the soil arching, resulting in a stress transfer from the subsoil to the pile cap (Figure 11(c)).

\section{Effect of pile spacing}

On increasing the pile spacing, the maximum settlement of subsoil in Figure 12(a) is significantly increased, particularly for larger pile spacing. As the pile spacing increases from 2.5 to $3.5 \mathrm{~m}$, the maximum subsoil settlement is found to increase by about $242 \%$. The pile spacing also has a pronounced influence on the subsoil stress and the $S_{\mathrm{CR}}$, as shown in Figures 12(b) and 12(c). Zhuang et al. (2010) reported that the ratio of the embankment height to the pile spacing is a key parameter for the development of soil arching, and when the pile spacing increases for a given embankment height, the soil arching is decreased, resulting in an increase of the stress carried by the subsoil (Figure 12(b)) and a decrease in $S_{\mathrm{CR}}$ (Figure 12(c)).

The results of the parametric study show that the maximum settlement of subsoil increases the most (i.e. 240\%) when increasing the pile spacing from a small value to a relatively large value (i.e. from 2.5 to $3.5 \mathrm{~m}$ ). The pile spacing is therefore the most sensitive factor to the maximum settlement of the subsoil. It also confirms that an embankment combined with very soft subsoil and a geogrid with relatively low stiffness may result in larger settlement of the subsoil and may cause intolerable geogrid strain.

\section{Comparison of analytical method and FEM}

Assuming that the tensile reinforcement corresponds to a uniform vertical load and deforms as a parabola, the vertical stress carried by the geogrid $\left(\sigma_{\mathrm{r}}\right)$ and the maximum settlement of geogrid $\left(\delta_{\mathrm{r}}\right)$ can be obtained based on following equation (Zhuang et al., 2014).

$$
\sigma_{\mathrm{r}}=\frac{64 J}{3 l}\left(\frac{\delta_{\mathrm{r}}}{l}\right)^{3}
$$

where $J$ is the stiffness of the geogrid and $l$ is the span of the geogrid and was taken as $l=(s-a)\left(1+2^{1 / 2}\right) / 2$; the maximum settlement of the geogrid $\left(\delta_{\mathrm{r}}\right)$ was assumed equal to the maximum settlement of subsoil $(\delta)$. Equation 5 can therefore be rearranged as follows.

6. $\delta=l\left(\frac{3 l}{64 J} \sigma_{\mathrm{r}}\right)^{(1 / 3)}$ 


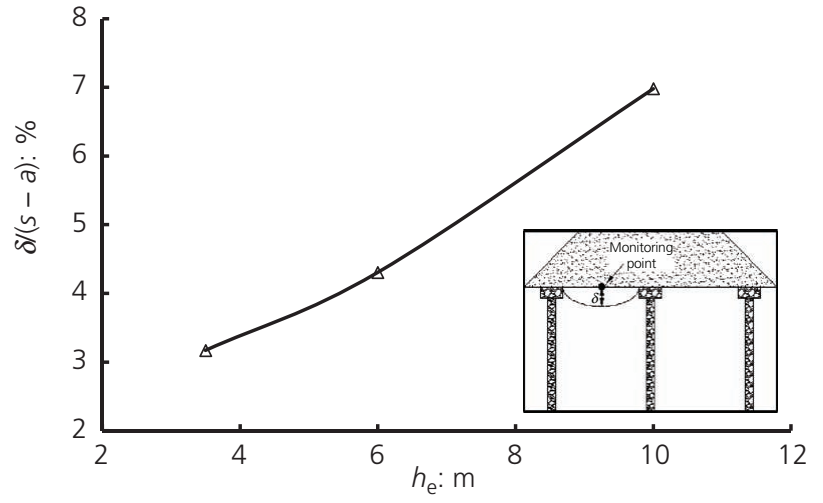

(a)

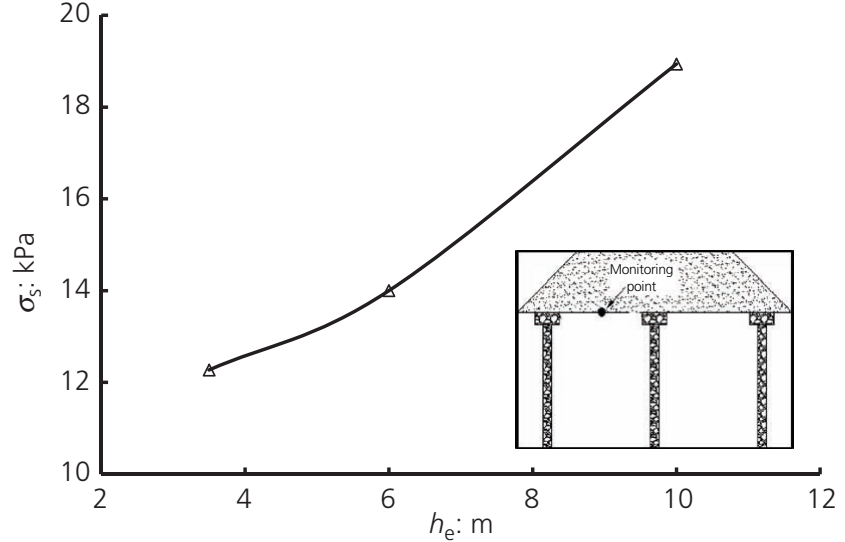

(b)

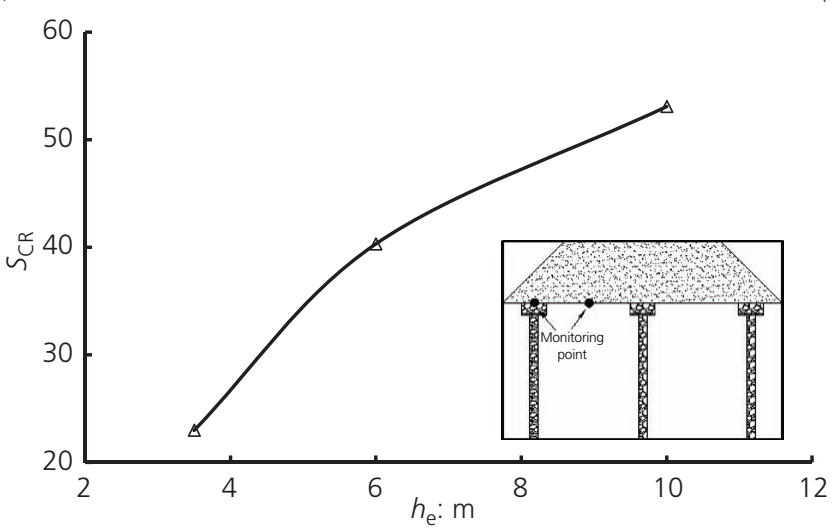

(c)

Figure 11. Effect of embankment height on the maximum settlement of subsoil, subsoil stress and $S_{C R}$ : (a) maximum settlement of the subsoil; (b) subsoil stress $\left(\sigma_{\mathrm{r}}\right)$; and (c) $S_{\mathrm{CR}}$

Figure 13 shows the comparison of the analytical method and FEM in terms of the vertical stress carried by the geogrid and the maximum settlement of the geogrid. In Figure 13(a), Equation 6 is plotted based on $s=2.5 \mathrm{~m}$ and with the total geogrid stiffness of $1.5 \mathrm{MN} / \mathrm{m}$ (each layer of $0.5 \mathrm{MN} / \mathrm{m}$ for the three-layer geogrid model and $1.5 \mathrm{MN} / \mathrm{m}$ for single-layer geogrid), which is relevant to all data. The single-layer and three-layer geogrids give similar results in terms of the geogrid stress and the maximum settlement of the geogrid. The maximum settlements of the geogrid from the FEM range from $25 \%$ lower to $7 \%$ higher than that predicted by the analytical method. The analytical method therefore shows reasonable agreement with the FEM.

The results of the comparison between the analytical method and the FEM varied with the pile spacing, as presented in Figure 13(b). As implied by Equation 6, the pile spacing $(s)$ has a significant impact on the settlement, particularly when it increases to relatively large values. As is shown in Figure 13(b), the difference of the results for the single-layer and three-layer geogrids are negligible. The maximum settlements of the geogrid for the FEM range from $25 \%$ lower to $6 \%$ higher than that predicted by the analytical method. A reasonable agreement is also observed between the analytical method and the FEM.
Figure 13 indicates that Equation 6 and, hence, Equation 5 can be used to predict the response of geogrid in terms of the settlement for a given vertical stress carried by the geogrid with reasonable accuracy. It reveals that the stress carried by the geogrid for a given settlement is directly proportional to the stiffness, but reduces dramatically with span as $l^{4}$. The stress carried by the geogrid increases rapidly with the settlement as $\delta^{3}$. It can also be concluded that the maximum settlement of the geogrid is more sensitive to the pile spacing compared to the geogrid stiffness.

\section{Conclusions}

Multiple layers of low-strength geogrid-reinforced piled embankments have been comprehensively investigated in this paper based on numerical simulations. It showed that the inclusion of the geogrid effectively enhanced the stress transfer from subsoil to pile caps, reduced the vertical stress acting on the subsoil and thus reduced the maximum settlement of the subsoil, particularly for stiffer geogrids. Although the settlement of threelayer and single-layer geogrids were approximately identical, the embankment with three-layer geogrid provided more uniform stress distribution on the top of the subsoil and resulted in less differential settlement through the embankment. It was also found that the maximum settlement and total tension of the geogrid were 


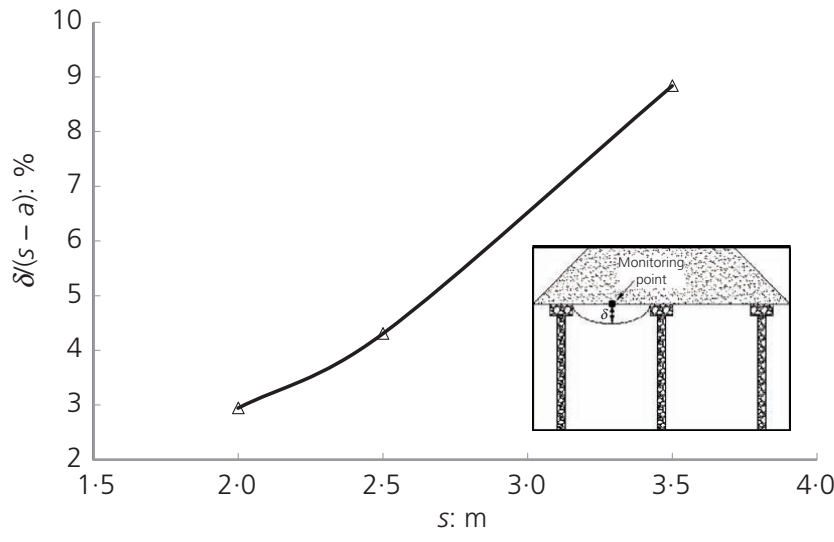

(a)

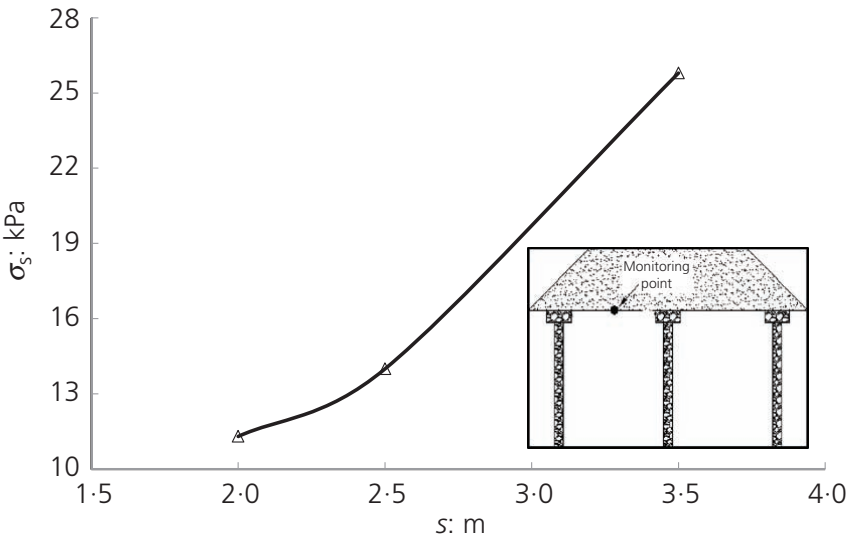

(b)

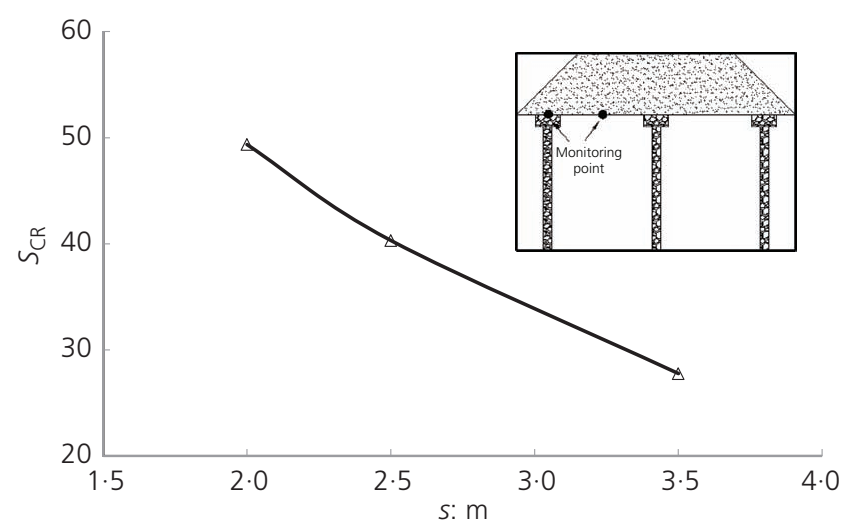

(c)

Figure 12. Effect of pile spacing on the maximum settlement of subsoil, subsoil stress and $S_{C R}$ : (a) maximum settlement of the subsoil; (b) subsoil stress $\left(\sigma_{\mathrm{r}}\right)$; and $(\mathrm{c}) S_{\mathrm{CR}}$

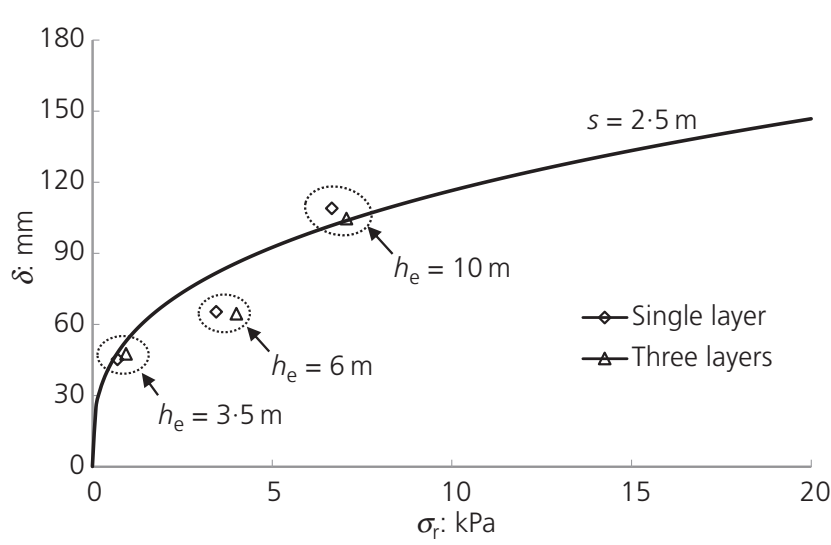

(a)

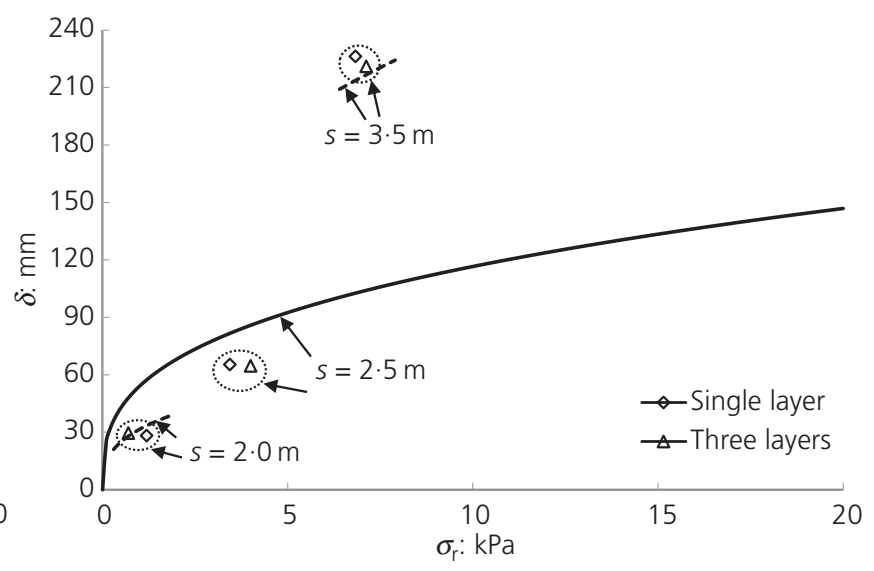

(b)

Figure 13. Comparison of analytical method and FEM for the settlement and geogrid stress: (a) effect of embankment height $(s=2 \cdot 5 \mathrm{~m}$, total stiffness $=1.5 \mathrm{MN} / \mathrm{m})$ and $(\mathrm{b})$ effect of pile spacing $\left(h_{\mathrm{e}}=6 \mathrm{~m}\right.$, total stiffness $\left.=1.5 \mathrm{MN} / \mathrm{m}\right)$ 
dependent only on the total stiffness provided and not on the number of reinforcement layers.

The parametric study showed that soil arching increased with the increase in compression index of the subsoil, geogrid stiffness and embankment height; it approached to a limiting value for relatively large geogrid stiffness, while decreasing with increasing the pile spacing. The pile spacing was found to be the most sensitive factor influencing the maximum settlement of the subsoil. The results demonstrate a combination of very soft subsoil and a geogrid with relatively low strength, resulting in intolerable geogrid strain, and caused excessive and continuing deformation of the load transfer platform.

An analytical method was finally assessed by the results of the FEM and showed reasonable agreement. The analytical method can therefore be used to predict the response of the geogrid, in terms of settlement for a given vertical stress carried by the geogrid, with reasonable accuracy.

\section{Acknowledgements}

The financial support of the National Natural Science Foundation of China (Grant Numbers 51478166 and 51420105013), the financial support sponsored by Qing Lan Project, the Fundamental Research Funds for the Central Universities (Grant Number 2016B04414, 2015B17814 and 2016B20614), National Key R\&D Program of China (2016YFC0502208) and 111 Project (Grant Number B13024) are acknowledged. The first author would like to acknowledge the support from the China Scholarship Council.

\section{REFERENCES}

Abdrabbo FM and Ali NA (2015) Behaviour of single pile in consolidating soil. Alexandria Engineering Journal 54(3): 481-495, https://doi.org/10.1016/j.aej.2015.05.016.

Abdullah CH and Edil TB (2007) Behaviour of geogrid-reinforced load transfer platforms for embankment on rammed aggregate piers. Geosynthetics International 14(3): 141-153, https://doi.org/10.1680/ gein.2007.14.3.141.

Ariyarathne P and Liyanapathirana DS (2015) Review of existing design methods for geosynthetic-reinforced pile-supported embankments. Soils and Foundations 55(1): 17-34, https://doi.org/10.1016/j.sandf. 2014.12.002.

Ariyarathne P, Liyanapathirana DS and Leo CJ (2012) Comparison of different two-dimensional idealizations for a geosynthetic reinforced pilesupported embankment. International Journal of Geomechanics 13(6): 754-768, https://doi.org/10.1061/(ASCE)GM.1943-5622.0000266.

Arulrajah A and Bo MW (2008) Characteristics of Singapore marine clay at Changi. Geotechnical and Geological Engineering 26(4): 431-441, https://doi.org/10.1007/s10706-008-9179-2.

Bell AL, Jenner C, Maddison JD and Vignoles J (1994) Embankment support using geogrids with vibro concrete columns. Fifth International Conference on Geotextiles, Geomembranes and Related Products, Singapore, pp. 335-338.

Bhasi A and Rajagopal K (2014) Geosynthetic-reinforced piled embankments: comparison of numerical and analytical methods. International Journal of Geomechanics 15(5): 04014074, https://doi. org/10.1061/(ASCE)GM.1943-5622.0000414.

Bo MW, Arulrajah A, Sukmak P and Horpibulsuk S (2015) Mineralogy and geotechnical properties of Singapore marine clay at Changi. Soils and Foundations 55(3): 600-613, https://doi.org/10.1016/j.sandf.2015. 04.011

Briancon L and Simon B (2012) Performance of pile-supported embankment over soft soil: full-scale experiment. Journal of Geotechnical and Geoenvironmental Engineering 138(4): 551-561, https://doi.org/10.1061/(ASCE)GT.1943-5606.0000561.

Briancon L and Villard P (2008) Design of geosynthetic-reinforced platforms spanning localized sinkholes. Geotextiles and Geomembranes 26(5): 416-428, https://doi.org/10.1016/j.geotexmem. 2007.12.005.

BSI (2010) BS 8006-1:2010: Code of practice for strengthened/reinforced soils and other fills. BSI, London, UK.

Chen RP, Xu ZZ, Chen YM, Ling DS and Zhu B (2010) Field tests on pilesupported embankments over soft ground. Journal of Geotechnical and Geoenvironmental Engineering 136(6): 777-785, https://doi.org/ 10.1061/(ASCE)GT.1943-5606.0000295.

Chen RP, Wang YW, Ye XW, Bian XC and Dong XP (2016) Tensile force of geogrids embedded in pile-supported reinforced embankment: a full-scale experimental study. Geotextiles and Geomembranes 44(2): 157-169, https://doi.org/10.1016/j.geotexmem. 2015.08.001.

Deb K and Mohapatra SR (2013) Analysis of stone column-supported geosynthetic reinforced embankments. Applied Mathematical Modelling 37(5): 2943-2960, https://doi.org/10.1016/j.apm.2012.07.002.

Di Donna A, Ferrari A and Laloui L (2015) Experimental investigations of the soil-concrete interface: physical mechanisms, cyclic mobilization, and behaviour at different temperatures. Canadian Geotechnical Journal 53(4): 659-672, https://doi.org/10.1139/cgj-2015-0294.

Ellis EA and Aslam R (2009) Arching in piled embankments: comparison of centrifuge tests and predictive methods - part 1 of 2 . Ground Engineering 42(6): 34-38.

GGS (German Geotechnical Society) (2011) Recommendations for Design and Analysis of Earth Structures using Geosynthetic Reinforcements EBGEO. Ernst \& Sohn, Berlin, Germany.

Gu F, Luo X, Luo R et al. (2016) Numerical modeling of geogridreinforced flexible pavement and corresponding validation using largescale tank test. Construction and Building Materials 122: 214-230, https://doi.org/10.1016/j.conbuildmat.2016.06.081.

Guido VA, Chang DK and Sweeney MA (1986) Comparison of geogrid and geotextile reinforced earth slabs. Canadian Geotechnical Journal 23(4): 435-440, https://doi.org/10.1139/t86-073.

Guido VA, Knueppel JD and Sweeny MA (1987) Plate loading tests on geogrid-reinforced earth slabs. In Geosynthetics '87: Conference Proceedings: Geosynthetics Conference '87. Industrial Fabrics Association International. St. Paul, MN, USA, pp. 216-225.

Halvordson KA, Plaut RH and Filz GM (2010) Analysis of geosynthetic reinforcement in pile-supported embankments, Part II: 3D cable-net model. Geosynthetics International 17(2): 68-76, https://doi.org/10. 1680/gein.2010.17.2.68.

Han J and Gabr MA (2002) Numerical analysis of geosynthetic reinforced and pile-supported earth platforms over soft soil. Journal of Geotechnical and Geoenvironmental Engineering 128(1): 44-53, https://doi.org/10.1061/(ASCE)1090-0241(2002)128:1(44).

Horpibulsuk S, Chinkulkijniwat A, Cholphatsorn A, Suebsuk J and Liu MD (2012) Consolidation behavior of soil-cement column improved ground. Computers and Geotechnics 43(6): 37-50, https://doi.org/10. 1016/j.compgeo.2012.02.003.

Huang J and Han J (2009) 3D coupled mechanical and hydraulic modeling of a geosynthetic-reinforced deep mixed column-supported embankment. Geotextiles and Geomembranes 27(4): 272-280, https:// doi.org/10.1016/j.geotexmem.2009.01.001.

Hussein MG and Meguid MA (2016) A three-dimensional finite element approach for modeling biaxial geogrid with application to geogridreinforced soils. Geotextiles and Geomembranes 44(3): 295-307, https://doi.org/10.1016/j.geotexmem.2015.12.004. 
Iglesia GR, Einstein HH and Whitman RV (1999) Determination of vertical loading on underground structures based on an arching evolution concept. In Proceedings of the 3rd National Conf on Geo-engineering for Underground Facilities. University of Illinois, Champaign-Urbana pp. 495-506.

Jamsawang P, Yoobanpot N, Thanasisathit N, Voottipruex P and Jongpradist $P$ (2016) Three-dimensional numerical analysis of a DCM column-supported highway embankment. Computers and Geotechnics 72: 42-56, https://doi.org/10.1016/j.compgeo.2015.11.006.

Jenck O, Dias D and Kastner R (2009) Three-dimensional numerical modeling of a piled embankment. International Journal of Geomechanics 9(3): 102-112, https://doi.org/10.1061/(ASCE)15323641(2009)9:3(102).

Jones BM, Plaut RH and Filz GM (2010) Analysis of geosynthetic reinforcement in pile-supported embankments. Part I: 3D plate model Geosynthetics International 17(2): 59-67, https://doi.org/10.1680/gein 2010.17.2.59.

Liu HL, Ng CW and Fei K (2007) Performance of a geogrid-reinforced and pile-supported highway embankment over soft clay: case study. Journal of Geotechnical and Geoenvironmental Engineering 133(12): 1483-1493, https://doi.org/10.1061/(ASCE)1090-0241(2007) 133:12(1483).

Lorenzo GA and Bergado DT (2004) Fundamental parameters of cementadmixed, clay-new approach. Journal of Geotechnical and Geoenvironmental Engineering 130(10): 1042-1050, https://doi.org/ 10.1061/(ASCE)1090-0241(2004)130:10(1042).

Lu W and Miao L (2015) A simplified 2-D evaluation method of the arching effect for geosynthetic-reinforced and pile-supported embankments. Computers and Geotechnics 65: 97-103, https://doi. org/10.1016/j.compgeo.2014.11.014.

Ma L, Shen SL, Luo CY and Xu YS (2011) Field evaluation on the strength increase of marine clay under staged construction of embankment. Marine Georesources and Geotechnology 29(4): 317-332, https://doi. org/10.1080/1064119X.2011.554965.

Maddison JD, Jones DB, Bell AL and Jenner CG (1996) Design and performance of an embankment supported using low strength geogrids and vibro concrete columns. In Geosynthetics - Applications, Design and Construction (De Groot MB, Den Hoedt G and Termaat RJ (eds)). Balkema, Rotterdam, the Netherlands, pp. 325-332.

Miao Y, Yao E, Luo H and Zhu H (2016) Seismic behavior of soil-pile-structure interaction with a modified Desai thin-layer interface element. Advances in Mechanical Engineering 8(12): 1-11, https://doi.org/10.1177/1687814016680940.

Perkins SW (2000) Constitutive modeling of geosynthetics. Geotextiles and Geomembranes 18(5): 273-292, https://doi.org/10.1016/S02661144(99)00021-7.

Potyondy JG (1961) Skin friction between various soils and construction materials. Geotechnique 11(4): 339-353, https://doi.org/10.1680/geot. 1961.11.4.339.

Russell D and Pierpoint N (1997) An assessment of design methods for piled embankments. Ground Engineering 30(10): 39-44.

Saad B, Mitri H and Poorooshasb H (2006) 3D FE analysis of flexible pavement with geosynthetic reinforcement. Journal of transportation Engineering 132(5): 402-415, https://doi.org/10.1061/(ASCE)0733947X(2006)132:5(402)

Shen SL, Ma L, Xu YS and Yin ZY (2013) Interpretation of increased deformation rate in aquifer IV due to groundwater pumping in Shanghai. Canadian Geotechnical Journal 50(11): 1129-1142, https:// doi.org/10.1139/cgj-2013-0042.

Stewart ME and Filz GM (2005) Influence of clay compressibility on geosynthetic loads in bridging layers for column-supported embankment. In GeoFrontiers 2005: Contemporary Issues in Foundation Engineering (Anderson JB, Phoon KK, Smith E and Loehr JE (eds)). American Society of Civil Engineers, Reston, VA, USA, GSP 131 (CD-ROM).
Van Eekelen SJM, Bezuijen A and van Tol AF (2011) Analysis and modification of the British Standard BS8006 for the design of piled embankments. Geotextiles and Geomembranes 29(3): 345-359, https://doi.org/10.1016/j.geotexmem.2011.02.001.

Van Eekelen SJM, Bezuijen A and van Tol AF (2015) Validation of analytical models for the design of basal reinforced piled embankments. Geotextiles and Geomembranes 43(1): 56-81, https:// doi.org/10.1016/j.geotexmem.2014.10.002.

Xing HF, Zhang Z, Liu HB and Wei H (2014) Large-scale tests of pilesupported earth platform with and without geogrid. Geotextiles and Geomembranes 42(6): 586-598, https://doi.org/10.1016/j.geotexmem. 2014.10.005.

Xu YS, Shen SL, Du YJ, Chai J and Horpibulsuk S (2013) Modelling the cutoff behavior of underground structure in multi-aquifer-aquitard groundwater system. Natural Hazards 66(2): 731-748, https://doi.org/ 10.1007/s11069-012-0512-y.

Yoo C (2010) Performance of geosynthetic-encased stone columns in embankment construction: numerical investigation. Journal of Geotechnical and Geoenvironmental Engineering 136(8): 1148-1160, https://doi.org/10.1061/(ASCE)GT.1943-5606.0000316.

Yoo C and Kim SB (2009) Numerical modeling of geosynthetic-encased stone column-reinforced ground. Geosynthetics International 16(3): 116-126, https://doi.org/10.1680/gein.2009.16.3.116.

Zhang L, Zhao MH and He W (2007) Working mechanism of two direction reinforced composite foundation. Journal of Central South University of Technology 14(4): 589-594, https://doi.org/10.1007/ s11771-007-0113-1.

Zhang C, Jiang G, Liu X and Buzzi O (2016) Arching in geogrid-reinforced pile-supported embankments over silty clay of medium compressibility: field data and analytical solution. Computers and Geotechnics 77: 11-25, https://doi.org/10.1016/j.compgeo.2016.03. 007.

Zhuang $Y$ and Ellis EA (2014) Finite-element analysis of a piled embankment with reinforcement compared with BS 8006 predictions. Géotechnique 64(11): 910-917, https://doi.org/10.1680/geot.14.P.110.

Zhuang Y and Ellis EA (2016) Finite-element analysis of a piled embankment with reinforcement and subsoil. Géotechnique 66(7): 596-601, https://doi.org/10.1680/jgeot.15.P.139.

Zhuang Y and Wang KY (2015) Three-dimensional behavior of biaxial geogrid in a piled embankment: numerical investigation. Canadian Geotechnical Journal 52(10): 1629-1635, https://oi.org/10.1139/cgj2014-0538.

Zhuang Y, Ellis EA and Yu HS (2010) Plane strain FE analysis of arching in a piled embankment. Proceedings of the Institution of Civil Engineers - Ground Improvement 163(4): 207-215, https://doi.org/10. 1680/grim.2010.163.4.207.

Zhuang Y, Ellis EA and Yu HS (2012) Three-dimensional finite-element analysis of arching in a piled embankment. Geotechnique 62(12): 1127-1131, https://doi.org/10.1680/geot.9.P.113.

Zhuang Y, Wang KY and Liu HL (2014) A simplified model to analyze the reinforced piled embankments. Geotextiles and Geomembranes 42(2): 154-165, https://doi.org/10.1016/j.geotexmem.2014.01.002.

\section{How can you contribute?}

To discuss this paper, please submit up to 500 words to the editor at journals@ice.org.uk. Your contribution will be forwarded to the author(s) for a reply and, if considered appropriate by the editorial board, it will be published as a discussion in a future issue of the journal. 